\title{
Early Silurian (Llandovery) graptolite assemblages of Saudi Arabia: biozonation, palaeoenvironmental significance and biogeography
}

\author{
Mark WILLIAMS ${ }^{1,{ }^{*}}$, Jan ZALASIEWICZ ${ }^{1}$, Hani BOUKHAMSIN ${ }^{2}$ and Christian CESARI ${ }^{2}$ \\ 1 University of Leicester, Department of Geology, Leicester LE1 7RH, UK \\ 2 Saudi Aramco, Geological Technical Services Division, Dhahran, Saudi Arabia
}

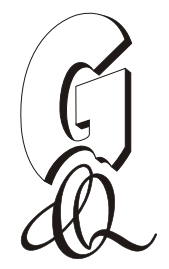

Williams, M., Zalasiewicz, J., Boukhamsin, H., Cesari, Ch., 2016. Early Silurian (Llandovery) graptolite assemblages of Saudi Arabia: biozonation, palaeoenvironmental significance and biogeography. Geological Quarterly, 60 (1): 3-25, doi: 10.7306/gq. 1270

\begin{abstract}
Analysis of Silurian graptolite assemblages from 1017 sample horizons in 132 cores (from 65 boreholes) through the Qusaiba Member, Qalibah Formation of Saudi Arabia, provides a refined graptolite biostratigraphy for the Arabian Peninsula comparable in its resolution to that from the British Isles and the Czech Republic. Over 150 graptolite species characterize 11 biozones from the lowermost Rhuddanian lubricus Biozone to the lower Telychian guerichi Biozone, with sub-zonal resolution for several intervals. Graptolite biozonal boundaries and the Rhuddanian-Aeronian and Aeronian-Telychian stage boundaries can be placed with high precision. Detailed analysis of graptolite spatial distribution suggests persistent depth-stratified marine assemblages across the Silurian palaeo-Arabian Plate. Near-surface-dwelling assemblages probably occupied the mixed-layer of Silurian oceans, enabling colonization of shallow shelf environments. They are low-diversity (1-2 species) assemblages characterized by Neodiplograptus, Coronograptus, Neolagarograptus and Stimulograptus species and often are preserved in strata with extensive shelly faunas. Deeper marine assemblages are of higher diversity (up to 15 species per horizon), and are characterized by dorsally curved or helically coiled species of Spirograptus, Demirastrites, Lituigraptus, Rastrites and Torquigraptus. Recognition of depth-stratified graptolite assemblages provides an important tool for establishing palaeo-basin topography and water depth at the time of sedimentary deposition. At the species level, the graptolite assemblages of Saudi Arabia are remarkably similar to contemporaneous faunas from peri-Gondwanan Europe and, from the middle Rhuddanian onwards, also to the Avalonian and Laurentian Llandovery graptolites of the UK.
\end{abstract}

Key words: Saudi Arabia, Silurian, graptolites, biozonation.

\section{INTRODUCTION}

Graptolites provide one of the most enduring and highly resolved macrofossil biostratigraphies for rocks of Ordovician and Silurian age (e.g., Elles and Wood 1901-1918; Zalasiewicz et al., 2009 and references therein). Their rapid evolution, manifested in a multitude of distinctive morphologies, enables their ready application to the establishment of biozonal schemes both at outcrop and in boreholes. In Saudi Arabia, graptolites have been reported from the Qusaiba Member of the Qalibah Formation, from rocks of Early Silurian (Llandovery) age (Rickards and Koren', 1974; El-Khayal, 1985, 1986, 1987a, b, c; McClure, 1988; Legrand in Mahmoud et al., 1992; Legrand in Vaslet et al., 1987; Legrand in Vaslet, 1989; Zalasiewicz et al., 2007). These works document "snapshots" of the graptolite fauna from strata of Rhuddanian, Aeronian and Telychian age. In this paper we establish the first integrated graptolite

* Corresponding author, e-mail: mri@leicester.ac.uk

Received: October 16, 2015; accepted: January 13, 2016; first published online: January 13, 2016 biostratigraphy for the Lower Silurian (Llandovery) of Saudi Arabia, identifying 11 biozones and a number of intervals of sub-zonal correlative importance, especially in the lower Telychian. We also establish the biogeographical and palaeoenvironmental importance of the fauna, commenting on the regional importance of the Saudi Arabian graptolites for interpreting the recovery of high-latitude Gondwanan graptolite assemblages after the Late Ordovician Hirnantian mass extinction.

\section{GEOLOGICAL SETTING}

During the Late Ordovician a continental-sized ice sheet was centred on sub-Saharan Africa, covering a large area of high southern latitude palaeocontinental Gondwana. The glacial advance resulted in the incision of deep valley systems by glacial and fluvial processes; these valleys have been traced into the subsurface of northern Saudi Arabia with seismic data (Konert et al., 2001). During earliest Silurian times, the Arabian Platform lay between $30^{\circ}$ and about $50^{\circ}$ latitude south. During the glacial maximum, the depositional setting of the latest Ordovician and Early Silurian northern Gondwana coast may have been analogous to the present-day Antarctic (Jones and Stump, 1999). As a major phase of global warming developed during the Llandovery, the glaciers began to retreat. The Ara- 


\begin{tabular}{|c|c|c|c|}
\hline \multicolumn{3}{|c|}{ Chronostratigraphy } & Lithostratigraphy \\
\hline \multirow{8}{*}{$\frac{\frac{c}{0}}{\frac{0}{2}}$} & $\begin{array}{l}\frac{\overline{0}}{\overline{0}} \\
\frac{0}{2} \\
\frac{1}{0}\end{array}$ & No stages & \multirow[t]{3}{*}{ Tawil Formation } \\
\hline & 3 & Ludfordian & \\
\hline & $\underline{3}$ & Gorstian & \\
\hline & 믐 & Homerian & \multirow{5}{*}{ Qusaiba Mbr } \\
\hline & 3 & Sheinwoodian & \\
\hline & \multirow{3}{*}{$\begin{array}{l}\geq \\
0 \\
0 \\
\frac{0}{0} \\
\frac{1}{0} \\
\frac{1}{J}\end{array}$} & Telychian & \\
\hline & & Aeronian & \\
\hline & & Rhuddanian & \\
\hline कें & $\begin{array}{l}\frac{1}{\bar{\nu}} \\
\frac{0}{2} \\
\frac{0}{2}\end{array}$ & Hirnantian & $\begin{array}{r}\text { Sarah Forma } \\
\text { Pre-Sarah unconformity }\end{array}$ \\
\hline
\end{tabular}

Fig. 1. Simplified Upper Ordovician and Silurian stratigraphy for Saudi Arabia (adapted from Senalp, 2006), showing the context of the graptolite-bearing Qusaiba Member of the Qalibah Formation

The major unconformities at the base of the Sarah and Tawil formations represent intervals of glacial lowstand

bian Platform flooded as sea level rose rapidly. In the marginal areas, shallow to open marine environments were established, while deeper marine environments covered the platform and extended southwards along a subsiding intra-shelf basin located in central Saudi Arabia. Anoxic bottom water conditions within the marine basins resulted in the preservation of organic-rich shales with graptolites. These form the shales of the Qusaiba Member in Saudi Arabia (Fig. 1), the Mudawwara Formation in Jordan, the Sahmah Formation in Oman, the Abba Formation in Syria, the Tanezzuft Formation in North Africa, the Dadas Formation in south-east Turkey, and the Ghakum Formation in Iran (Konert et al., 2001).

In Saudi Arabia, the shales of the Qusaiba Member are encountered in many subsurface boreholes: their thickness ranges from 420 to $914 \mathrm{~m}$ (1400 to $3000 \mathrm{ft}$ ). In some boreholes they can be completely eroded by younger unconformities. The Qusaiba Member has traditionally been considered as the lower member of the Early Silurian Qalibah Formation (see Fig. 1), which was first defined by Mahmoud et al. (1992) in the Al-Qalibah-Tayma area to replace the Tayyarat Formation of Vaslet et al. (1987) for the same lithostratigraphic succession. The Qalibah Formation, which includes a significant part of the Silurian System in Saudi Arabia, consists of the shale-dominated Qusaiba Member in its lower part and sand-dominated Sharawra Member in its upper part. The base of the Qalibah Formation is generally characterized by a disconformable, erosional or non-depositional contact with the underlying glaciogenic deposits of the Late Ordovician Sarah Formation. Further discussion of this stratigraphy can be found in Vaslet et al. (1994), Janjou et al. (1996), Senalp et al. (2002), and Miller and Al-Ruwaili (2007).

The Qusaiba Member represents the interval between the worldwide marine transgressive surface MFS S10 of Sharland et al. (2001) at its base, and a type-1 sequence boundary (erosional unconformity surface) at its top (Senalp, 2006). The "Qusaiba hot-shale facies," an interval of extremely organic-rich graptolite-bearing shales forming the main hydrocarbon source of the Paleozoic formations in Saudi Arabia, occurs in the basal part of the Qusaiba Member and is dated to the Rhuddanian Stage of the Llandovery Series. The "hot shale" interval is diachronous, and usually about $10-30 \mathrm{~m}$ thick, and is interbedded with variable amounts of well to moderately sorted, very fine grained sandstones and coarse siltstones (Jones and Stump, 1999). The Aeronian part of the Qusaiba Member contains a distinctive interval, usually between about 30 to $60 \mathrm{~m}$ thick, that is significantly more sandy than the deposits occurring immediately below and above it. This sandstone body has been termed the "mid-Qusaiba Sand" by Wender et al. (1998). Miller and Melvin (2005) interpreted the mid-Qusaiba Sand as being associated with a lowstand event.

\section{MATERIAL STUDIED, REPOSITORY, AND NOTE ON THE CONFIDENTIALITY OF DATA FROM INDIVIDUAL BOREHOLES}

The material studied here is sourced from 1017 sample horizons, from 65 boreholes and 132 cores that penetrated the Qusaiba Member (Fig. 2). Precise geographical and biostratigraphical details of individual boreholes in Saudi Arabia are unavailable due to operational confidentiality and therefore here we provide a summary of the graptolite biostratigraphy of these cores, following the style of the paper by Rickards (1976) for the UK graptolite succession. Some cores sampled in the 1970s have suffered extensive pyrite decay, but the more recent cores, which make up the bulk of material studied, provide well-preserved graptolites. The cores penetrate a range of lithologies including black pyritic mudstones, hemipelagic mudstones, turbiditic grey mudstones, siltstones and sandstones. Graptolites have been recovered from all of these lithologies but the best-preserved and most diverse material is yielded from black mudstones. For the latter, sampling of the core is possible to centimetric accuracy, enabling biozonal and stage boundaries to be identified with precision: in the continuous cores we have sampled, fracture zones or faulting have not disrupted the continuity of the graptolite ranges and biozones. Core material and the figured graptolites are stored in the collections of the Saudi Arabian Oil Company (Saudi Aramco) Dhahran, Saudi Arabia.

\section{GRAPTOLITE BIOSTRATIGRAPHY}

The biostratigraphical distribution of over 150 graptolite species in the Lower Silurian rocks of Saudi Arabia relative to the graptolite biozones that we recognize are summarized in Figure 3. In all, 11 graptolite biozones are recognized, extending from the lowermost Silurian Normalograptus lubricus Biozone to the lower Telychian guerichi Biozone (Fig. 3). In some Aramco cores a near-continuous succession of biozones from the Rhuddanian to lower Telychian can be established, with the first and last occurrences of the graptolites placed with accuracy. In our analysis of cores we have prioritized the identification of biozone and subzone boundaries. Thus, we expect 


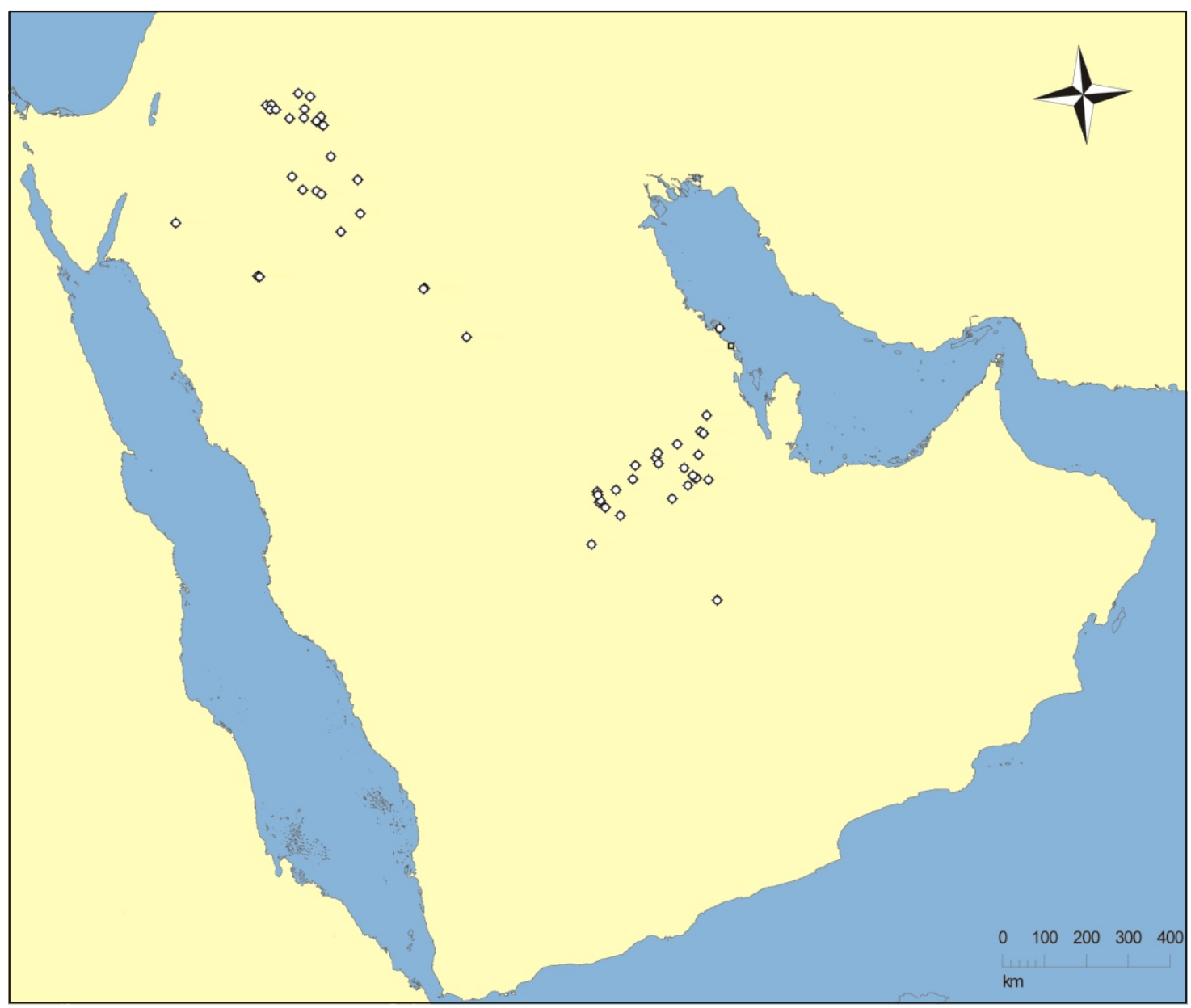

Fig. 2. Regional distribution of graptolite-bearing boreholes drilled by the Saudi Arabian Oil Company on the Arabian Peninsula

The graptolite dataset comprises 1017 sample horizons, from 65 boreholes and 132 cores that penetrate the Qusaiba Member. Some borehole sites that are situated in close proximity to each other are superimposed in the figure

that with further intra-zonal analysis the complement of graptolite species and resolution of the graptolite biostratigraphy can be further refined. A number of younger graptolites have also been recovered, including possible Streptograptus johnsonae Loydell (suggesting the lower turriculatus Biozone), and those indicative of higher levels in the Telychian (Retiolites geinitzianus (Barrande), Stimulograptus clintonensis (Hall). At present this graptolite material is scant and it cannot be placed in a continuous succession of biozones; therefore, it is not treated here.

The Arabian succession shows a marked degree of similarity in the first and last occurrences of key species that are used to define the graptolite biozonal scheme applied to the UK (Zalasiewicz et al., 2009 and references therein), and we therefore largely follow this biozonal scheme. Representative illustrations of the graptolites are shown in Figures 4-13.

\section{NORMALOGRAPTUS LUBRICUS BIOZONE}

The stratigraphically lowest graptolite assemblages recovered from core in the Qusaiba Member are dominated by Normalograptus ajjeri (Legrand), Normal.? parvulus $(\mathrm{H}$. Lapworth), Normal. normalis (Lapworth), Normal. angustus (Perner), Normal.? cf. lungmaensis (Sun), Normal. medius
(Törnquist), Normal. bifurcatus Loydell, Normal. targuii Legrand, and Normal. mirnyensis (Obut and Sobolevskaya in Obut et al.). Similar assemblages in Jordan have been assigned an age of either latest Ordovician or earliest Silurian (see Loydell, 2007), but unpublished palynological data in Saudi Arabia suggests this level is likely to be in the earliest Rhuddanian. Typically no more than two graptolite species are present at any one horizon in this interval. Normal.? cf. persculptus (Elles and Wood) is recorded, albeit rarely, whilst Normal. lubricus (Chen and Lin) is present sporadically from near the base of this interval: elsewhere, this latter species has been used as an indicator for the base of the Silurian (Koren' and Melchin, 2000), as it is, tentatively, here.

\section{AKIDOGRAPTUS ASCENSUS-PARAKIDOGRAPTUS ACUMINATUS BIOZONE}

The ascensus-acuminatus Biozone was originally distinguished (as the acuminatus Biozone) by Lapworth (1878) in the Birkhill Shales Formation of southern Scotland and in its original definition also embraced the graptolites of the underlying persculptus Biozone (see Zalasiewicz et al., 2009: 827). In Saudi Arabia this biozone is characterized by more than 20 graptolite species that enable its subdivision into two intervals 
Graptolite biozones and graptolite species

Neodiplograptus daedalus Normalograptus angustus Normalograptus lubricus Normalograptus bifurcatus Normalograptus? persculptus Normalograptus? parvulus Normalograptus? lungmaensis Normalograptus targuii Normalograptus normalis Normalograptus medius Normalograptus mirnyensis Normalograptus rectangularis Normalograptus ajjeri Nediplograptus shanchongensis Normalograptus jideliensis

Akidograptus ascensus

Nediplograptus apographon

Neodiplograptus lanceolatus

Normalograptus cortoghianensis

Neodiplograptus sp. 3 sensu Loydell

Normalograptus longifilis

Neodiplograptus parajanus

Parakidograptus acuminatus

Normalograptus minor

Normalograptus trifilis

Neodiplograptus africanus

Sudburigraptus sp.

Huttagraptus incurvus

Rhaphidograptus extenuatus

Neodiplograptus elongatus

Huttagraptus praestrachani

Metaclimacograptus slalom

Huttagraptus sp. 2 of Koren' \& Bjerreskov

Neodiplograptus fezzanensis

Cystograptus vesiculosus

Huttagraptus acinaces

Dimorphograptus confertus s.I.

Normalograptus tariti

Pribylograptus sandersoni

Atavograptus atavus

Rhaphidograptus toernquisti

Glyptograptus tamariscus s.I.

Metaclimacograptus hughesi

Metaclimacograptus undulatus s.I.

Glyptograptus sinuatus s.I.

Coronograptus cyphus

Neodiplograptus sp. A

Monograptus revolutus

Monograptus sudburiae

Coronograptus gregarius

Demirastrites triangulatus predecipiens

Pristiograptus concinnus

Rastrites longispinus

Pribylograptus incommodus

Demirastrites triangulatus triangulatus

"Paraclimacograptus" libycus

Neodiplograptus thuringiacus

Pseudorthograptus insectiformis

Glyptograptus incertus

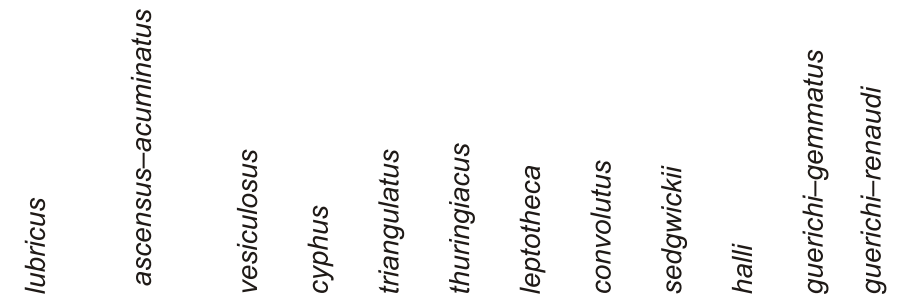

\section{Fig. 3A - stratigraphic distribution of over 150 graptolite taxa in the Qusaiba Member, Qalibah Formation}

Ranges are compiled from an analysis of 1017 sample horizons. Note that the range chart identifies specimens of Metaclimacograptus hughesi (Nicholson), here used in the sense of Zalasiewicz (1996: text-fig. 2A-C) 


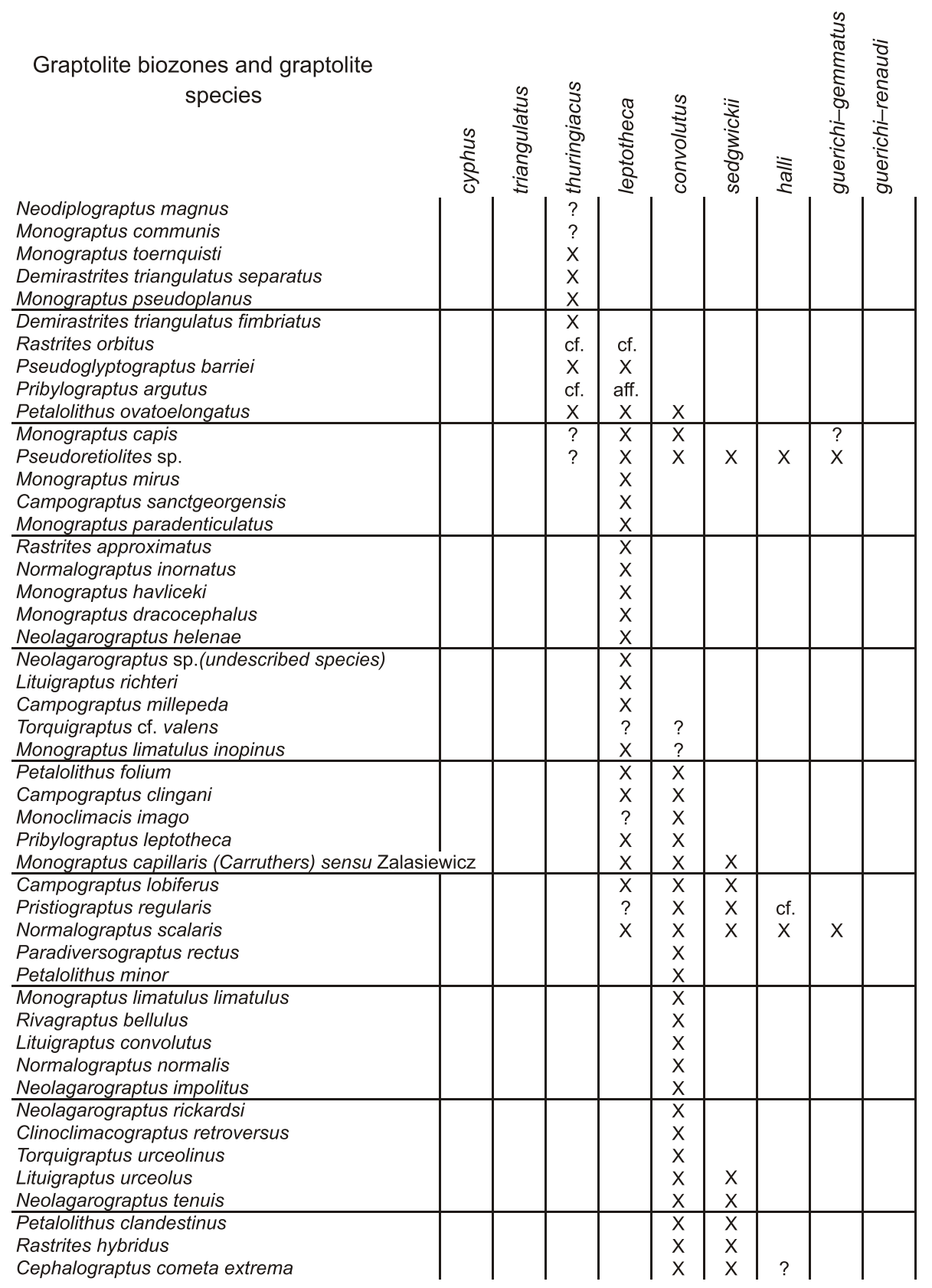

Fig. 3B - stratigraphic distribution of over 150 graptolite taxa in the Qusaiba Member, Qalibah Formation

(Fig. 3A). The base of the biozone is defined by the first appearance of Akidograptus ascensus Davies, and together with the first occurrences of Neodiplograptus lanceolatus Štorch and Serpagli (often in abundance), Neodiplogr. shanchongensis (Li), Neodiplogr. cf. apographon (Štorch), Normal. cortoghianensis (Štorch and Serpagli) and Normalograptus cf. jideliensis (Koren' and Mikhaylova) these collectively characterize the lower subdivision of the ascensus-acuminatus Biozone in Saudi Arabia and this interval can be correlated with the equivalent interval in Jordan (Loydell, 2007: text-fig. 6) and continental Europe (Štorch, 1996). The upper part of the ascensus-acuminatus Biozone is signalled by the first occurrence of
Parakidograptus acuminatus (Nicholson), Normalograptus triflis (Manck) - often in flood proportions, Normal. longifilis (Manck), Normal. rectangularis (McCoy), together with Neodiplograptus africanus (Legrand), Neodipl. parajanus (Štorch), and Sudburigraptus sp. The lower part of this interval is probably comparable to the middle ascensus-acuminatus Biozone of Jordan (Loydell, 2007) and continental Europe (Štorch, 1996), but the Saudi Arabian interval may also overlap the upper ascensus-acuminatus Biozone of the European and Jordanian schemes. In Saudi Arabia, abundant $P$. acuminatus appear just above the level with Normal. trifilis. 
Graptolite biozones and graptolite species

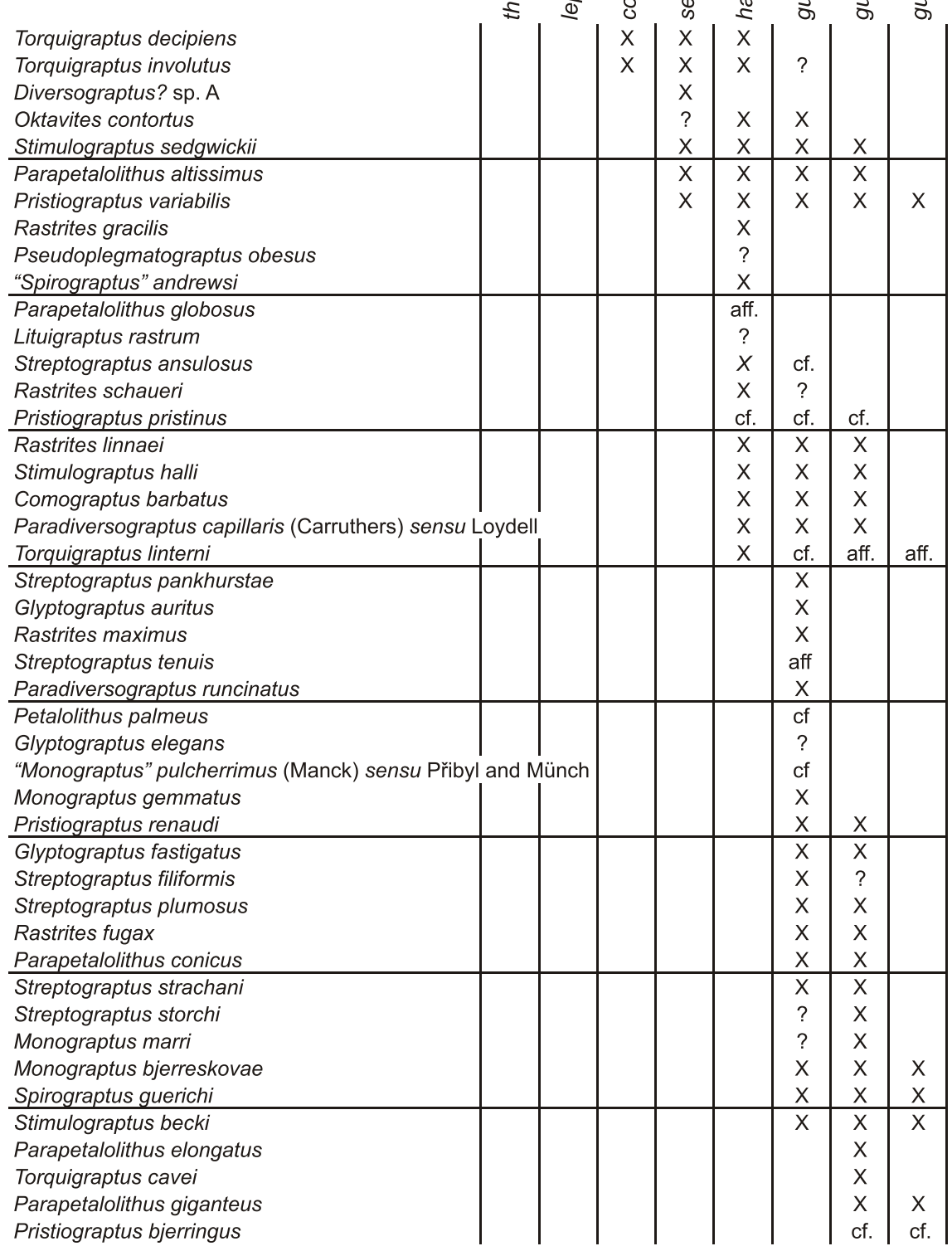

Fig. 3C - Stratigraphic distribution of over 150 graptolite taxa in the Qusaiba Member, Qalibah Formation

\section{CYSTOGRAPTUS VESICULOSUS BIOZONE}

The vesiculosus Biozone was distinguished in the Birkhill Shales Formation of Scotland by Lapworth (1878) and is here defined by the first appearance of its eponymous species, Cystograptus vesiculosus (Nicholson), which is abundant. Storch (1996) noted the co-occurrence of $C$. vesiculosus with the latest populations of $P$. acuminatus, regarding this level as the lowermost part of the vesiculosus Biozone. We have not been able to demonstrate such overlap. The lowermost $C$. vesiculosus in Saudi Arabia are accompanied by Normalograptus cf. tariti and normalograptids (Normal. medius, Normal. rectangularis, Normal. ajjeri) that range up from underlying levels. In Britain the interval represented by the vesiculosus Biozone was subdivided into the Atavograptus atavus and Huttagraptus acinaces biozones (see discussion in Hutt, 1974; Zalasiewicz et al., 2009), but in Saudi Arabia these subdivisions have proved unworkable, as the first appearances of Huttagraptus species, including $H$. praestrachani (Hutt and Rickards) and Huttagraptus sp. 2 of Koren' and Bjerreskov (1997), and Atavograptus atavus (Jones) are effectively coincident. The vesiculosus Biozone assemblage includes some 25 graptolite species in Saudi Arabia (Fig. 3A). Rhaphidograptus extenuatus (Elles and Wood), though rare, is present in lower assemblages of the vesiculosus Biozone while the upper part of the biozone is characterized by the first occurrences of long-ranging Metaclimacograptus spp. and Rhaphidograptus toernquisti (Elles and Wood), and by Dimorphograptus 

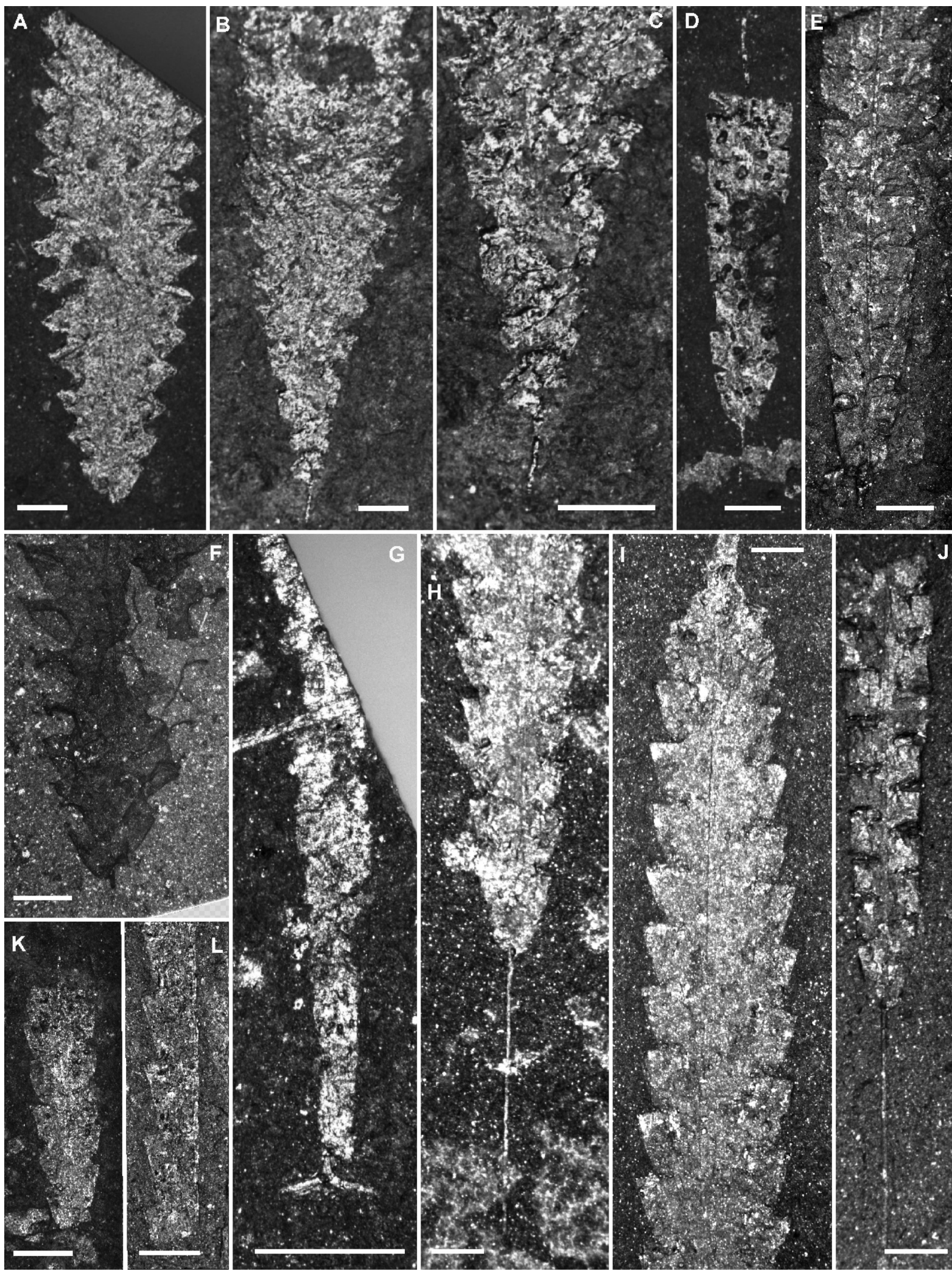

Fig. 4. Illustrative images of Rhuddanian graptolites from the Qusaiba Member of Saudi Arabia

A - Neodiplograptus lanceolatus; B, C - Neodiplograptus fezzanensis: C is a close-up of the proximal end of B; D, E Neodiplograptus africanus; F - Neodiplograptus lueningi; G - Akidograptus ascensus; $\mathbf{H}, \mathbf{I}$ - Neodiplograptus parajanus, proximal and distal part of rhabdosome respectively; J - Normalograptus ajjeri; K - Normalograptus? parvulus; L - Atavograptus atavus, distal fragment; scale bars are $1 \mathrm{~mm}$ 

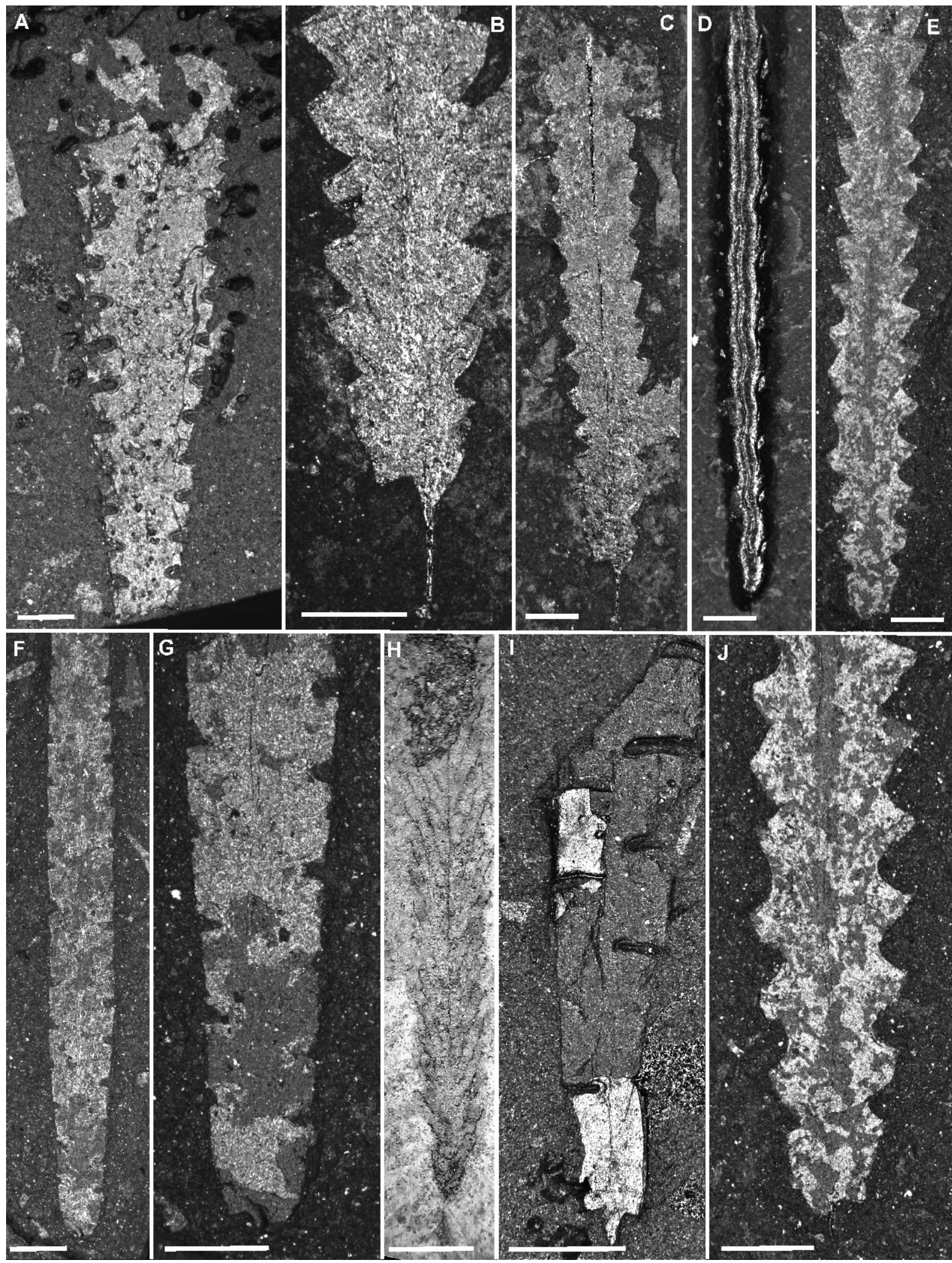

Fig. 5. Illustrative images of Rhuddanian graptolites from the Qusaiba Member of Saudi Arabia

A - "Paraclimacograptus" libycus?; B, C - Sudburigraptus sp: B is a close-up of the proximal end of C; D - Clinoclimacograptus retroversus Bulman and Rickards; E, J - Neodiplograptus cf. apographon: $\mathbf{J}$ is a close-up of the proximal end of E; F, G Normalograptus ajjeri: $\mathrm{G}$ is a close-up of the proximal end of F; H - Neodiplograptus cf. shanchongensis; I - Rhaphidograptus toernquisti; scale bars are $1 \mathrm{~mm}$ 

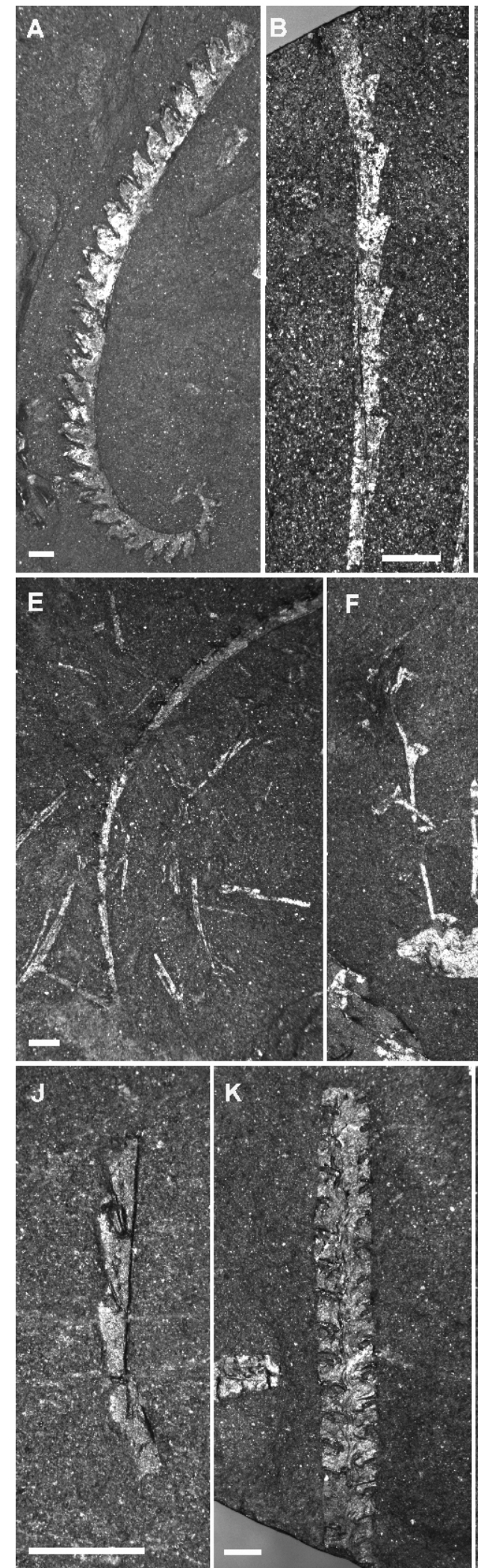

4.

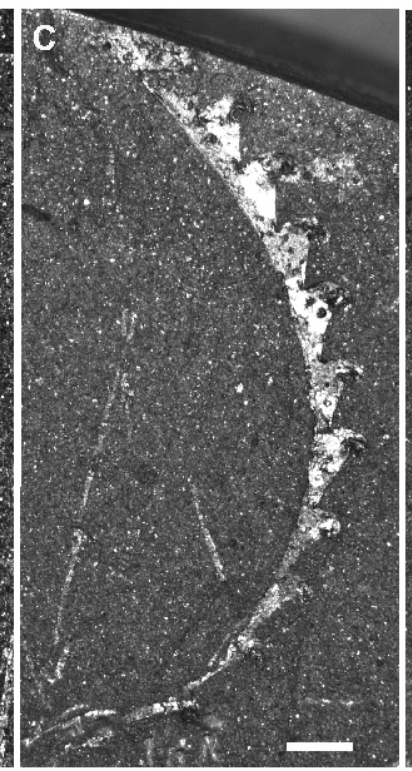

\section{D.}
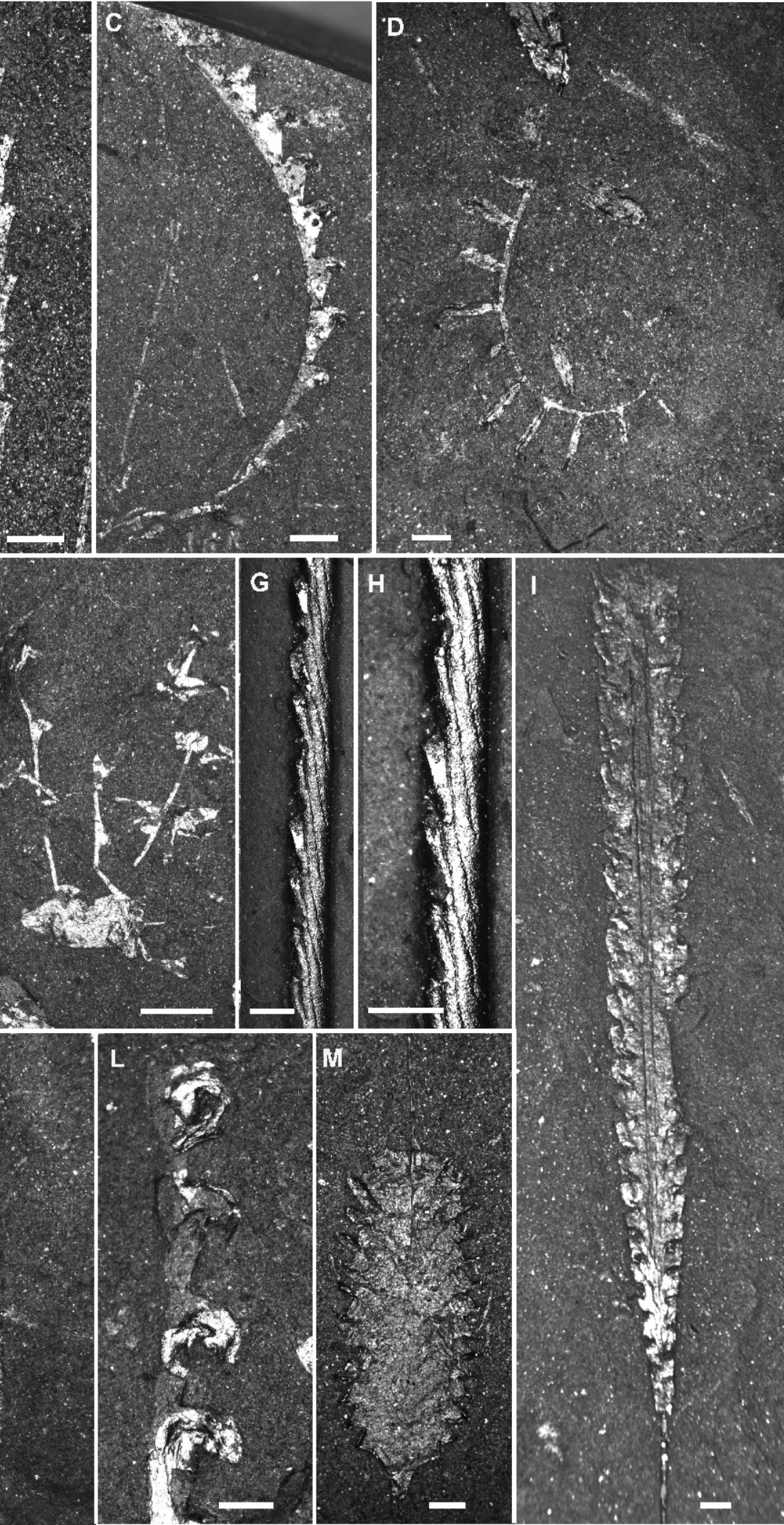

10
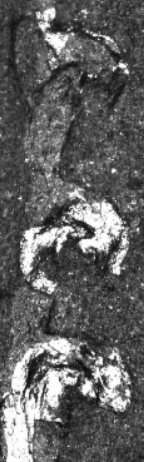
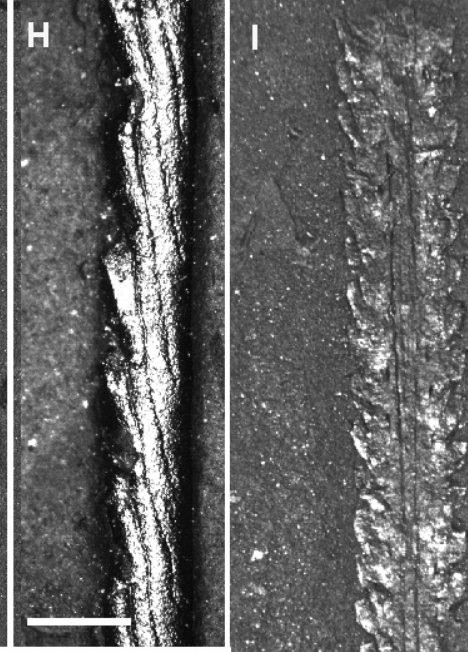

6!

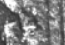

M
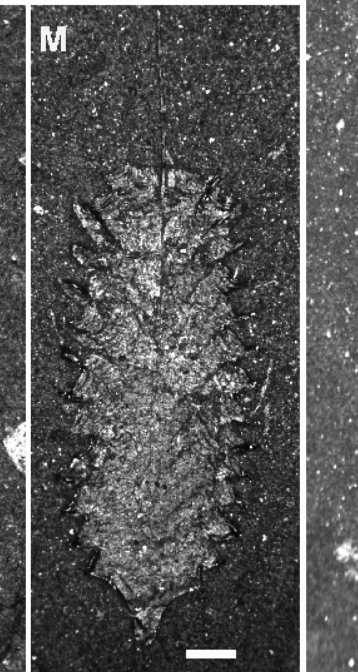

Fig. 6. Illustrative images of Aeronian graptolites from the Qusaiba Member of Saudi Arabia

A - Demirastrites triangulatus fimbriatus; B - Coronograptus gregarius; C - Monograptus pseudoplanus; D - Rastrites cf. orbitus; E - Monograptus sudburiae; F - Monograptus capis; G, H - Pribylograptus leptotheca: H is a close-up of G; I Neodiplograptus thuringiacus; J - Pristiograptus regularis; K - Metaclimacograptus hughesi sensu Zalasiewicz (1996); L Campograptus lobiferus; $\mathbf{M}$ - Petalolithus ovatoelongatus; scale bars are $1 \mathrm{~mm}$ 


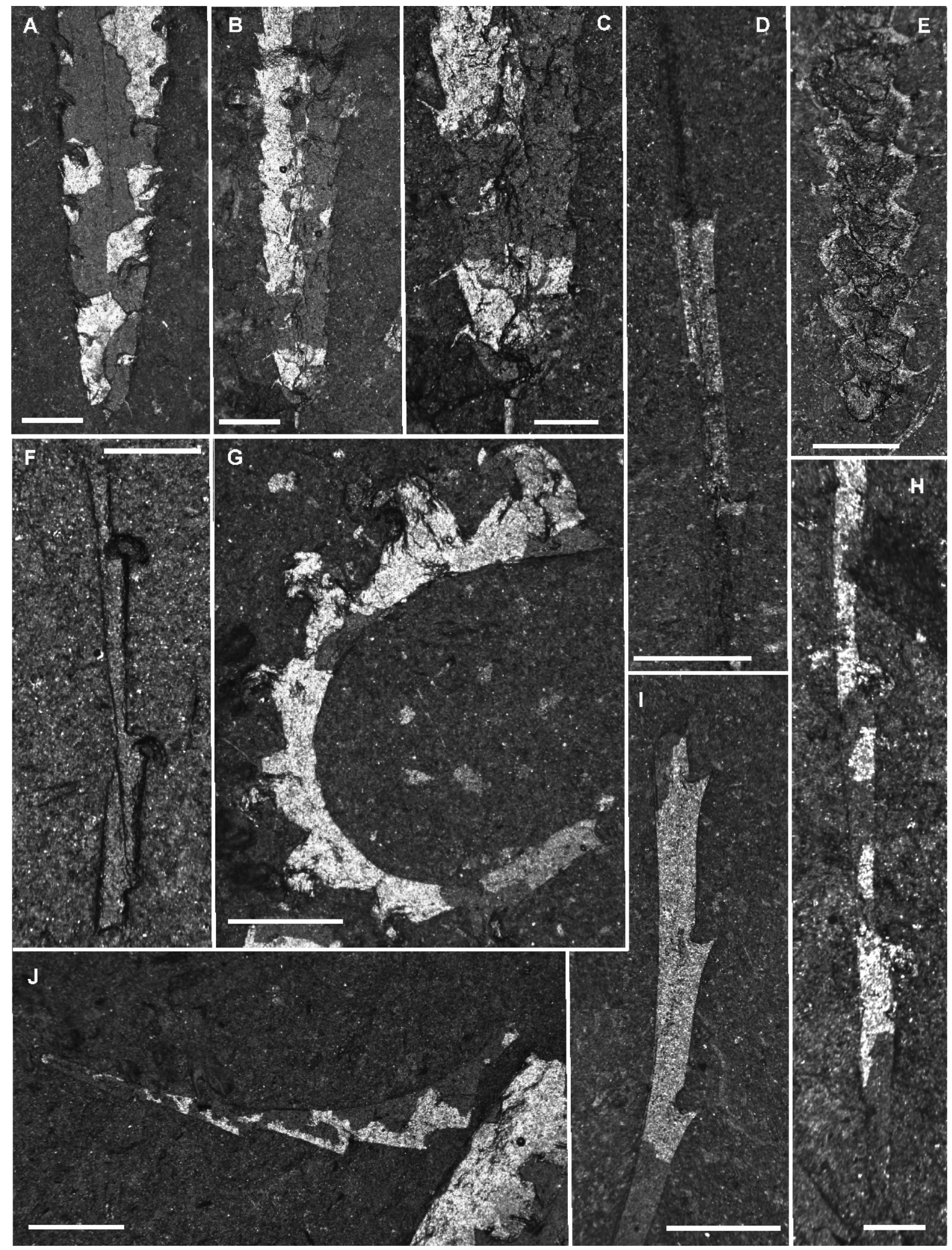

Fig. 7. Illustrative images of Aeronian graptolites from the Qusaiba Member of Saudi Arabia

A - Pseudoglyptograptus barriei; B, C - narrow specimen of Rivagraptus bellulus, approaching the dimensions of Rivagraptus rozmanae Koren' and Rickards: $\mathbf{C}$ is a close-up of the proximal end of B; D - Neolagarograptus sp. (possibly N. helenae); E Pseudorthograptus insectiformis; $\mathbf{F}$ - Campograptus sanctgeorgensis; G-Campograptus millepeda; $\mathbf{H}$-Monograptus capillaris sensu Zalasiewicz (1996); I - Neolagarograptus impolitus; J - Monograptus limatulus; scale bars are: A, B, D, E, G, I, J - 1 mm, $\mathrm{C}, \mathrm{F}-0.5 \mathrm{~mm}, \mathrm{H}-0.25 \mathrm{~mm}$ 

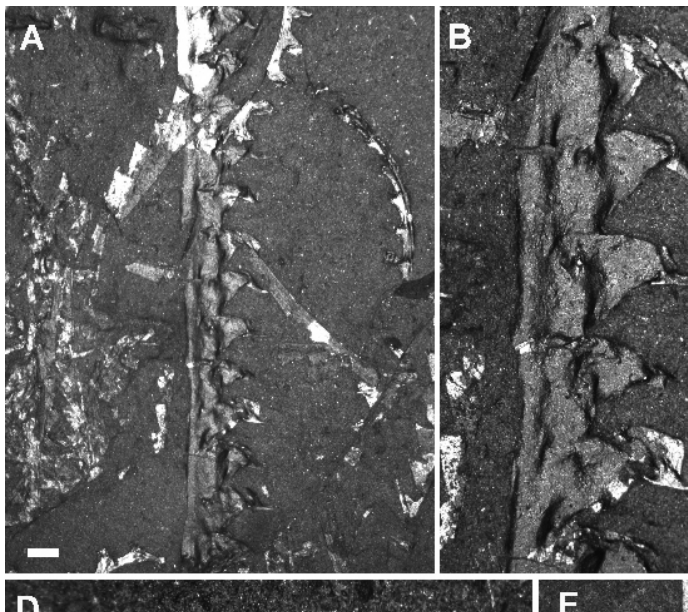

D
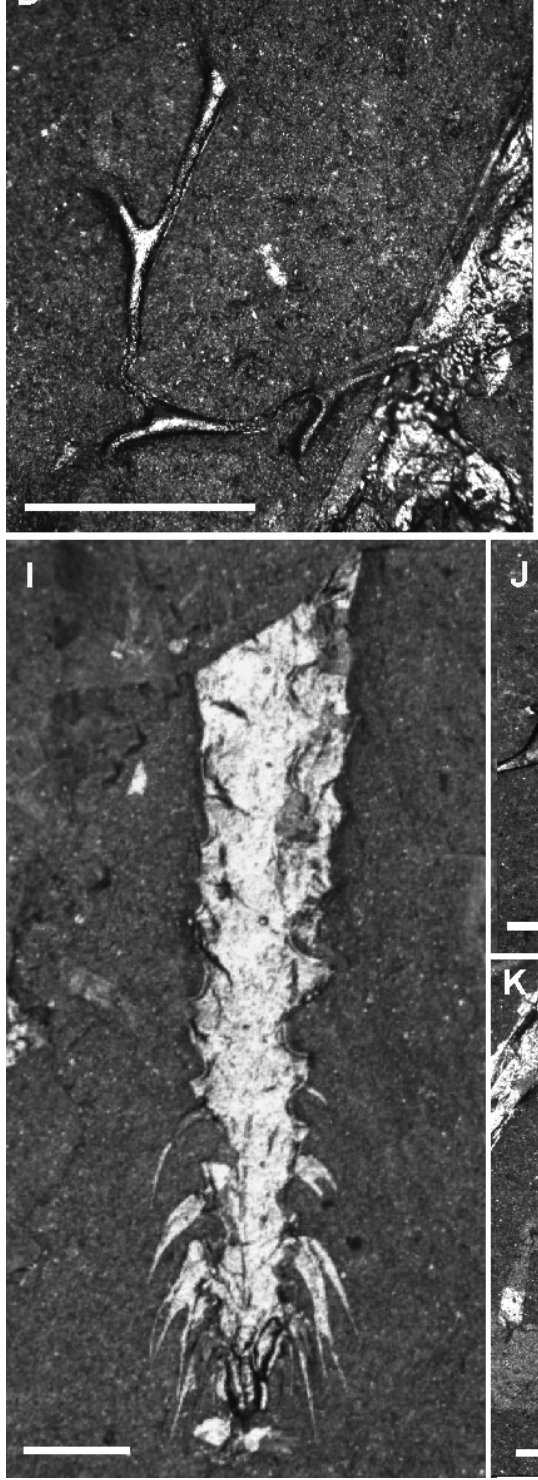

B.

E
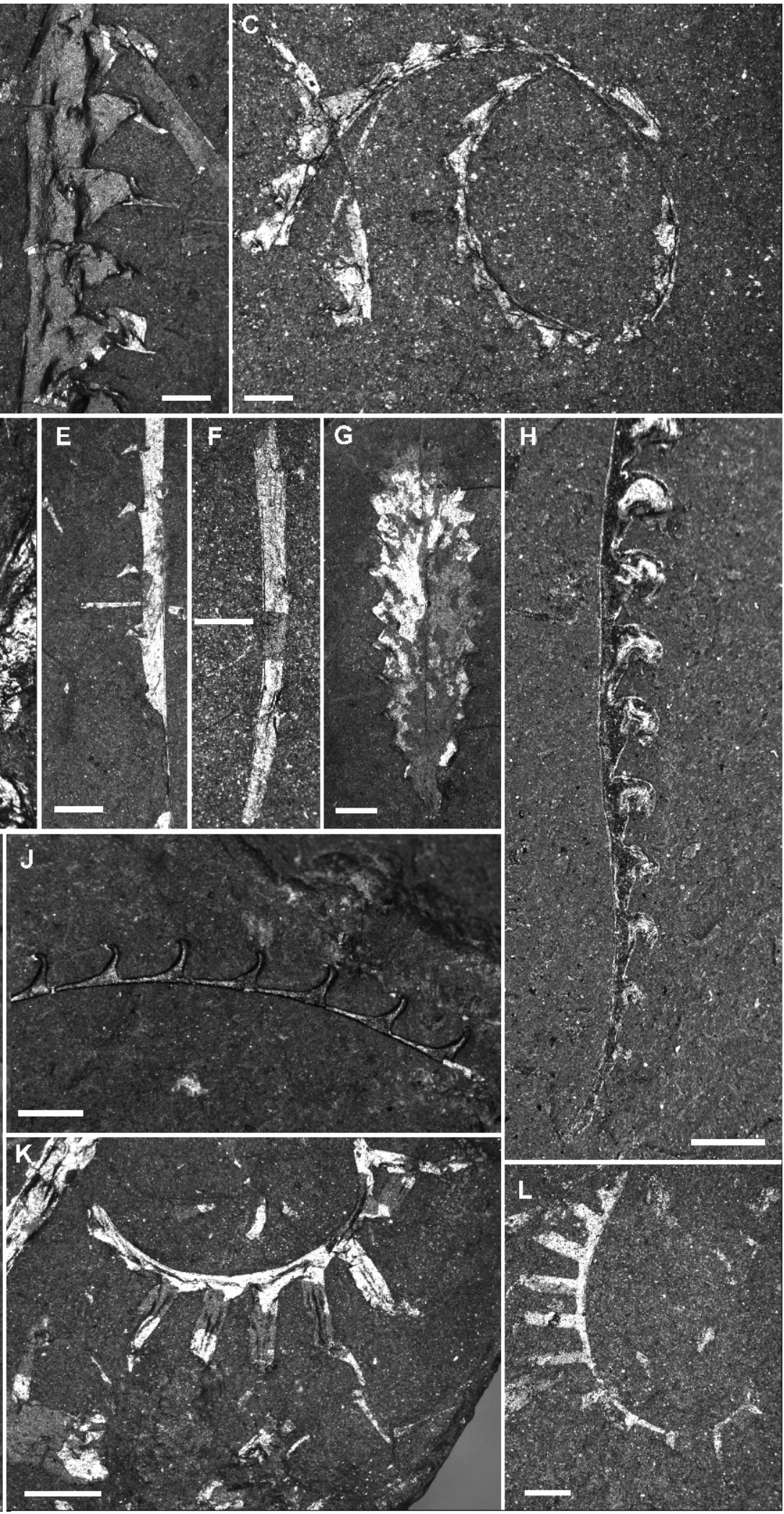

Fig. 8. Illustrative images of Aeronian (A, B, D-L) and Telychian (C) graptolites from the Qusaiba Member of Saudi Arabia

A, B - Torquigraptus involutus and Stimulograptus sedgwickii: B is a close-up of the thecae of S. sedgwickii in A; C Torquigraptus linterni; D - Torquigraptus decipiens; E, F - Neolagarograptus tenuis; G - Parapetalolithus altissimus; $\mathbf{H}$ Campograptus lobiferus; I - Comograptus barbatus; J - Torquigraptus sp. (possibly T. urceolinus); K - Lituigraptus convolutus; $\mathrm{L}$ - Lituigraptus sp.; scale bars are $1 \mathrm{~mm}$ 


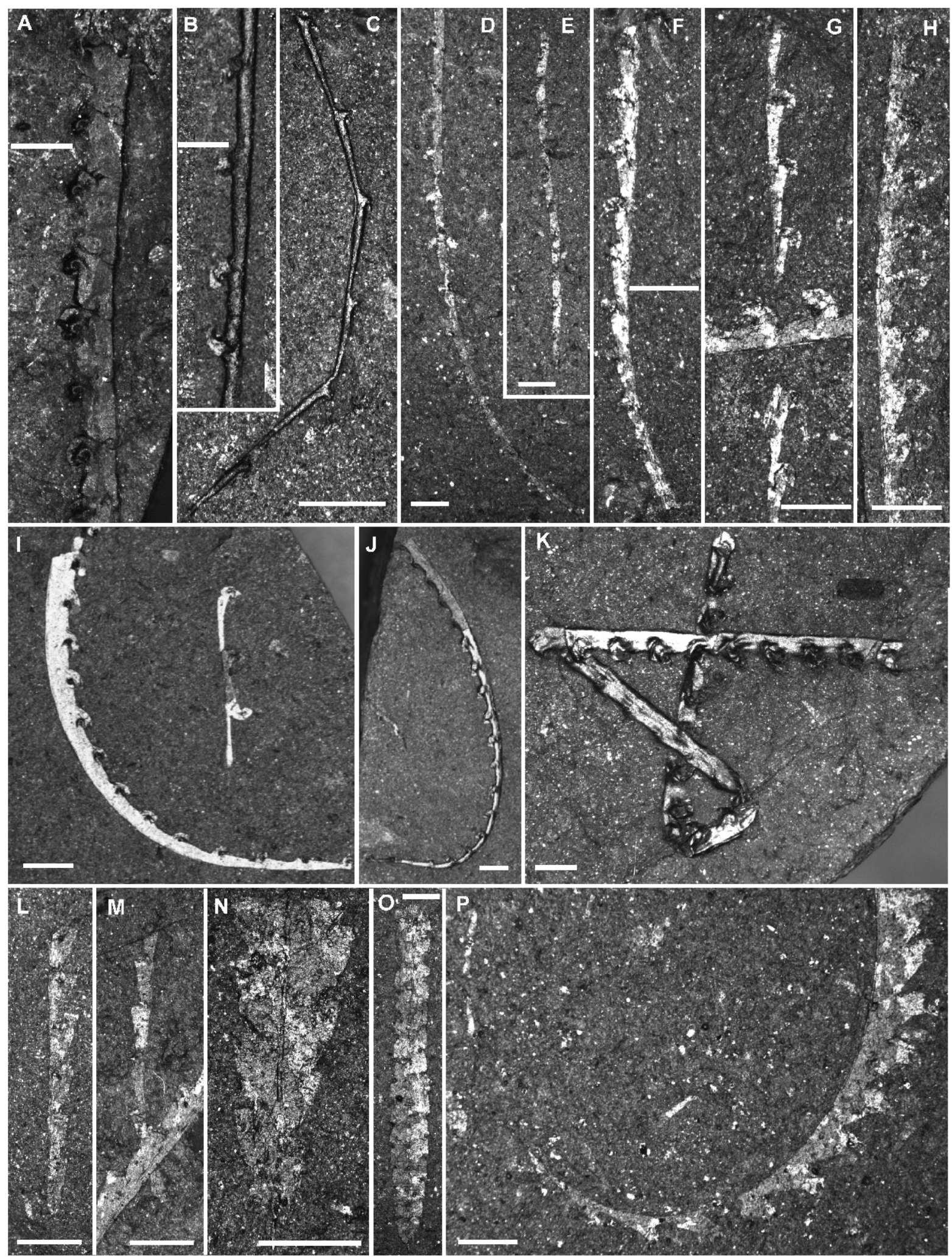

Fig. 9. Illustrative images of Telychian graptolites from the Qusaiba Member of Saudi Arabia

A - Streptograptus storchi?; B, C - Paradiversograptus capillaris sensu Loydell (1993); D - Stimulograptus becki; E Streptograptus strachani; F - Monograptus bjerreskovae; G - Monograptus gemmatus; $\mathbf{H}$ - Monograptus gemmatus, distal part of rhabdosome; I - Monograptus gemmatus proximal fragment and Streptograptus; J - Streptograptus pankhurstae; $\mathbf{K}$ Monograptus bjerreskovae that has likely been predated (hence folding of rhabdosome); $\mathbf{L}$ - Pristiograptus variabilis; $\mathbf{M}$ Pristiograptus renaudi; $\mathbf{N}$ - Glyptograptus auritus; $\mathbf{O}$ - Metaclimacograptus scalaris; P - Torquigraptus cavei; scale bars: A, C-P $-1 \mathrm{~mm}, \mathrm{~B}-0.5 \mathrm{~mm}$ 

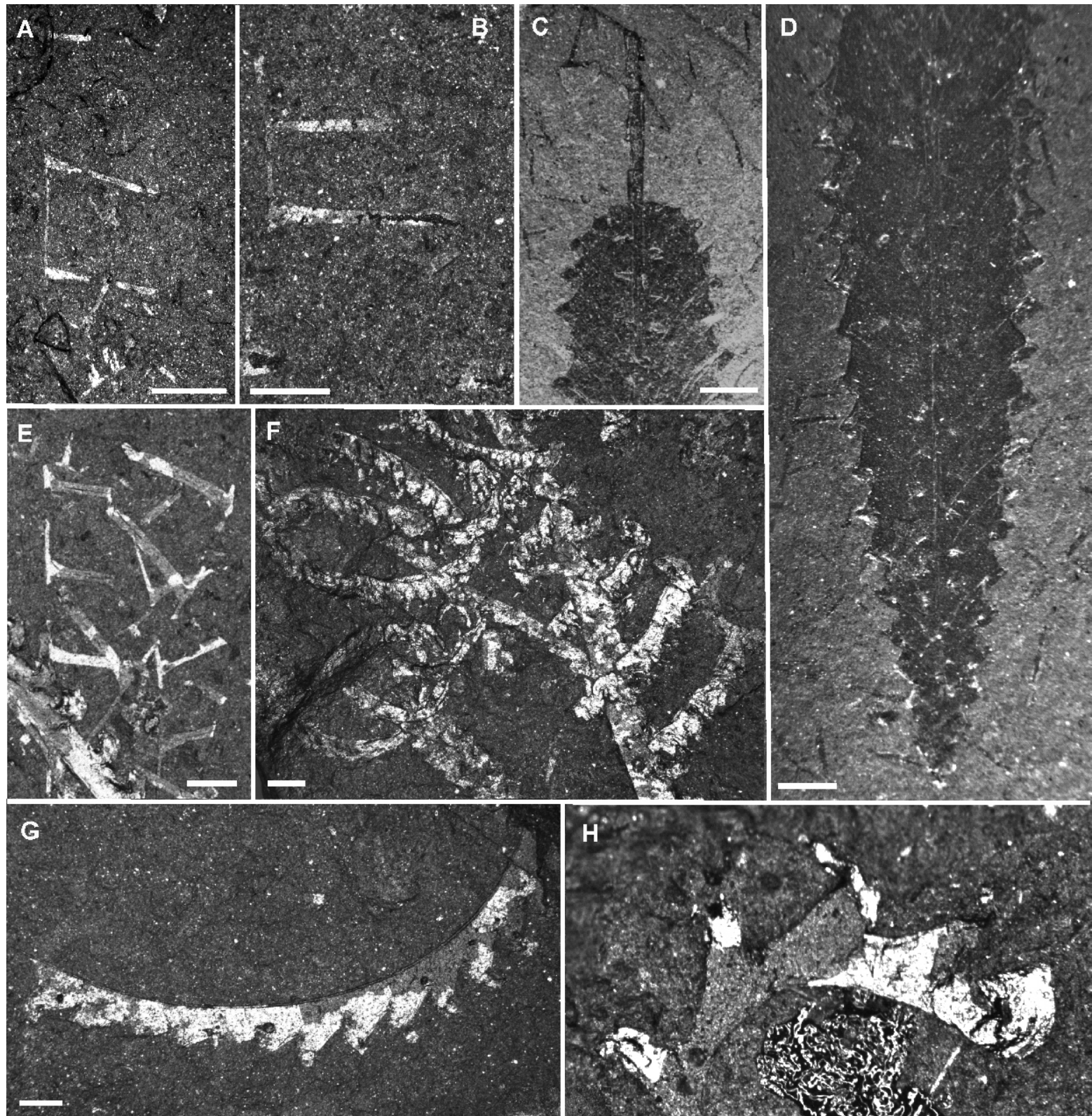

(a)
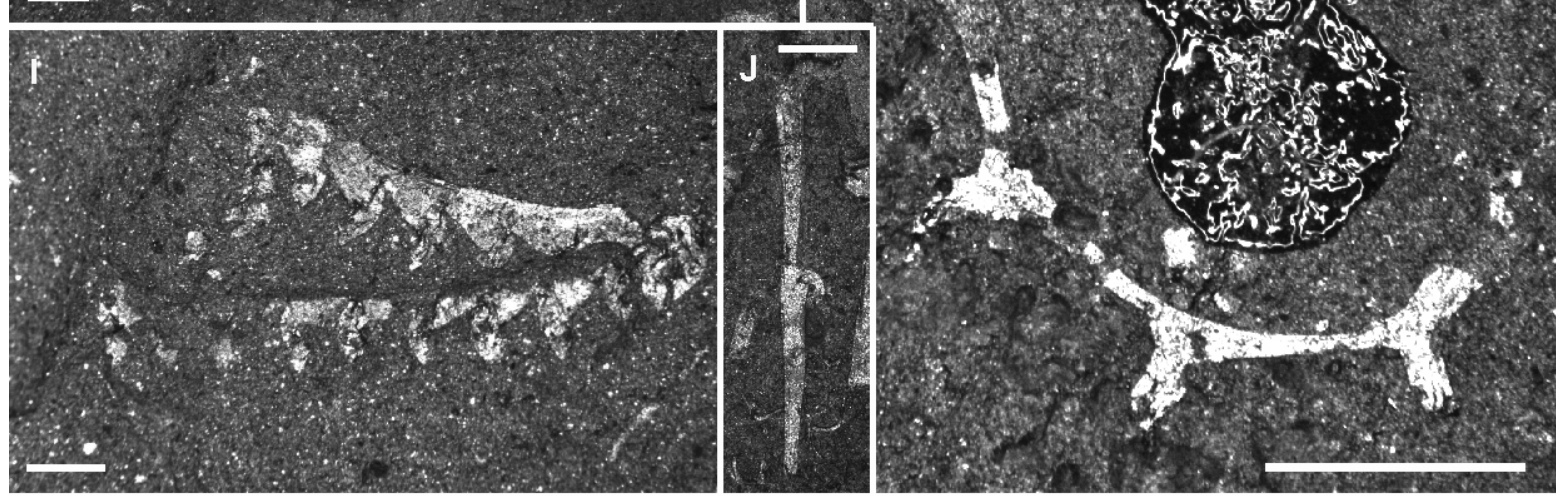

Fig. 10. Illustrative images of Late Aeronian and Telychian graptolites from the Qusaiba Member of Saudi Arabia

A, B, E - fragments of Rastrites spp.; C, D - Parapetalolithus giganteus, distal, and proximal and mesial parts of the same rhabdosome, respectively; F - Spirograptus guerichi; G - Oktavites contortus?; H - "Spirograptus" andrewsi?; I - Oktavites contortus?; J - Streptograptus cf. ansulosus; scale bars: A - 2 mm, B-I, H-1 mm, J - $0.5 \mathrm{~mm}$ 


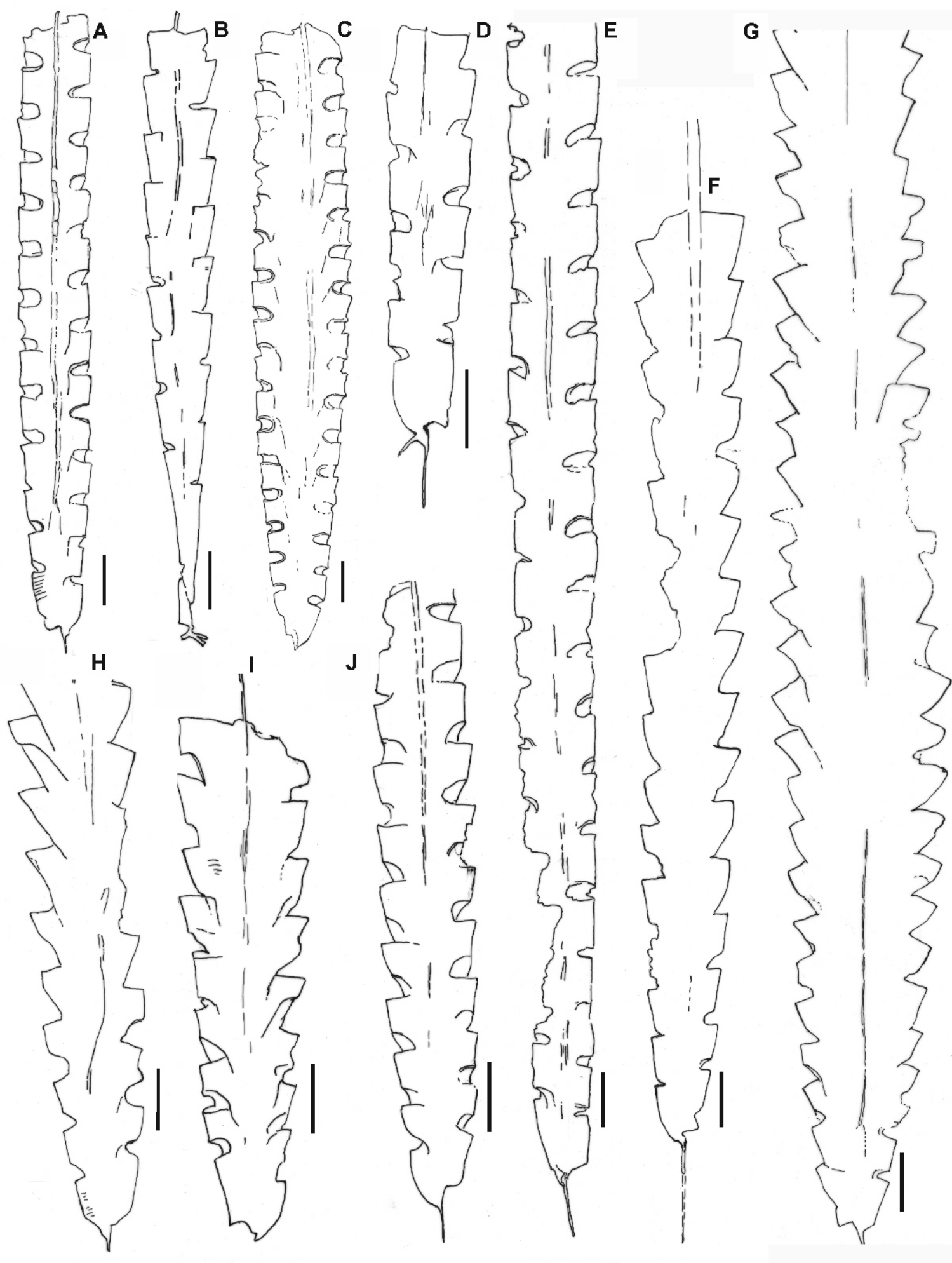

Fig. 11. Illustrative camera lucida images of Rhuddanian graptolites from the Qusaiba Member of Saudi Arabia

A - Normalograptus cf. jideliensis; B - Akidograptus ascensus; C - Normalograptus medius; D - Normalograptus lubricus; E Normalograptus normalis; F - Normalograptus? cf. lungmaensis; G - Neodiplograptus lanceolatus; H - Neodiplograptus aff. daedalus; I -Normalograptus? cf. persculptus; J - Normalograptus? parvulus; scale bars are $1 \mathrm{~mm}$ 


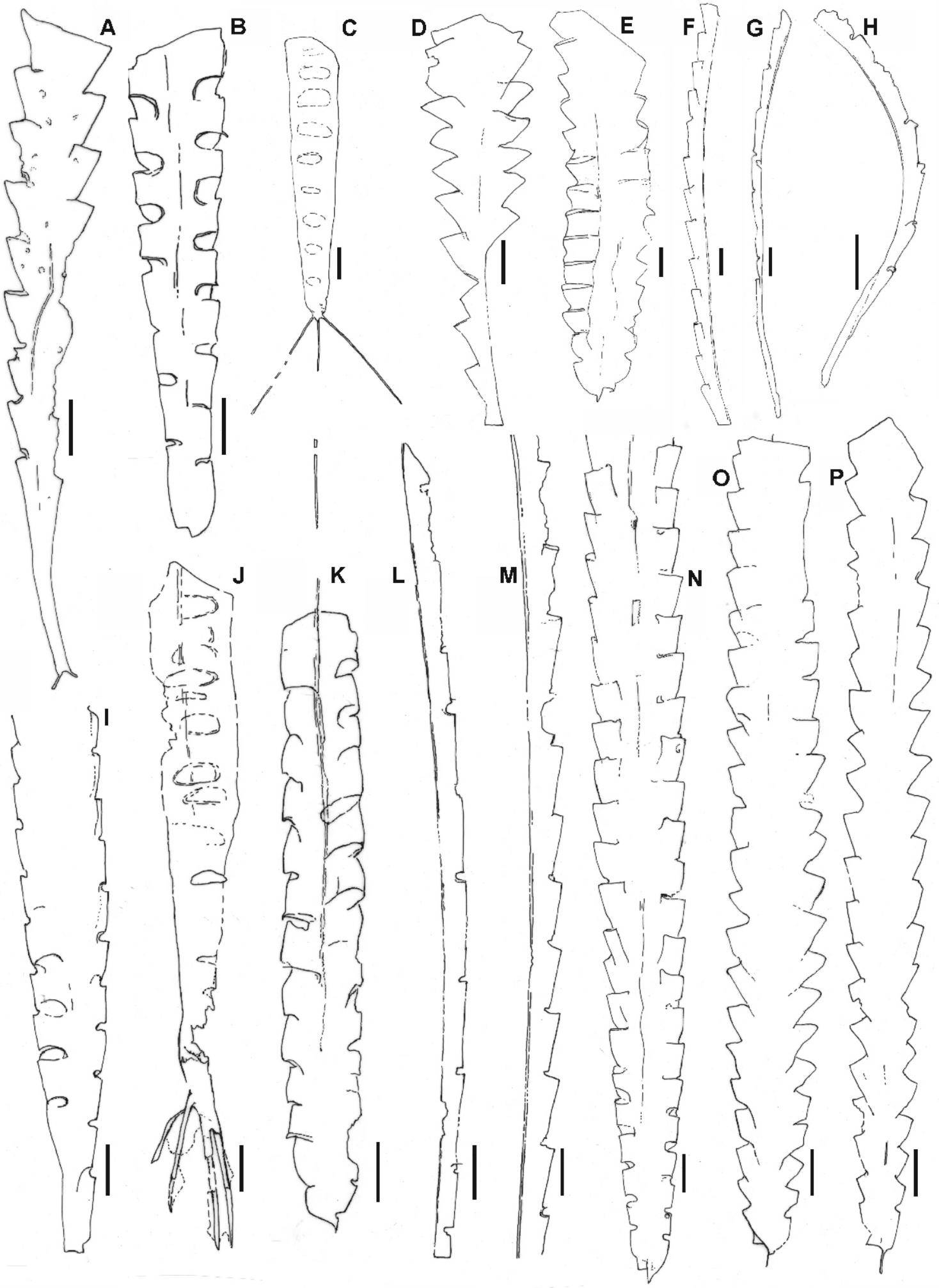

Fig. 12. Illustrative camera lucida images of Rhuddanian graptolites from the Qusaiba Member of Saudi Arabia

A - Parakidograptus acuminatus; B - Normalograptus rectangularis; C - Normalograptus trifilis; D - Dimorphograptus confertus s.l.; E - Cystograptus vesiculosus; F - Atavograptus sp.; G - Huttagraptus praestrachani; H - Huttagraptus incurvus?; I Rhaphidograptus toernquisti; J - Normalograptus longifilis; K - Metaclimacograptus hughesi sensu Zalasiewicz (1996); L, M Huttagraptus sp. 2 of Koren' and Bjerreskov; N - Neodiplograptus parajanus; O - Neodiplograptus cf. apographon; P Normalograptus cf. tariti; scale bars are $1 \mathrm{~mm}$ 


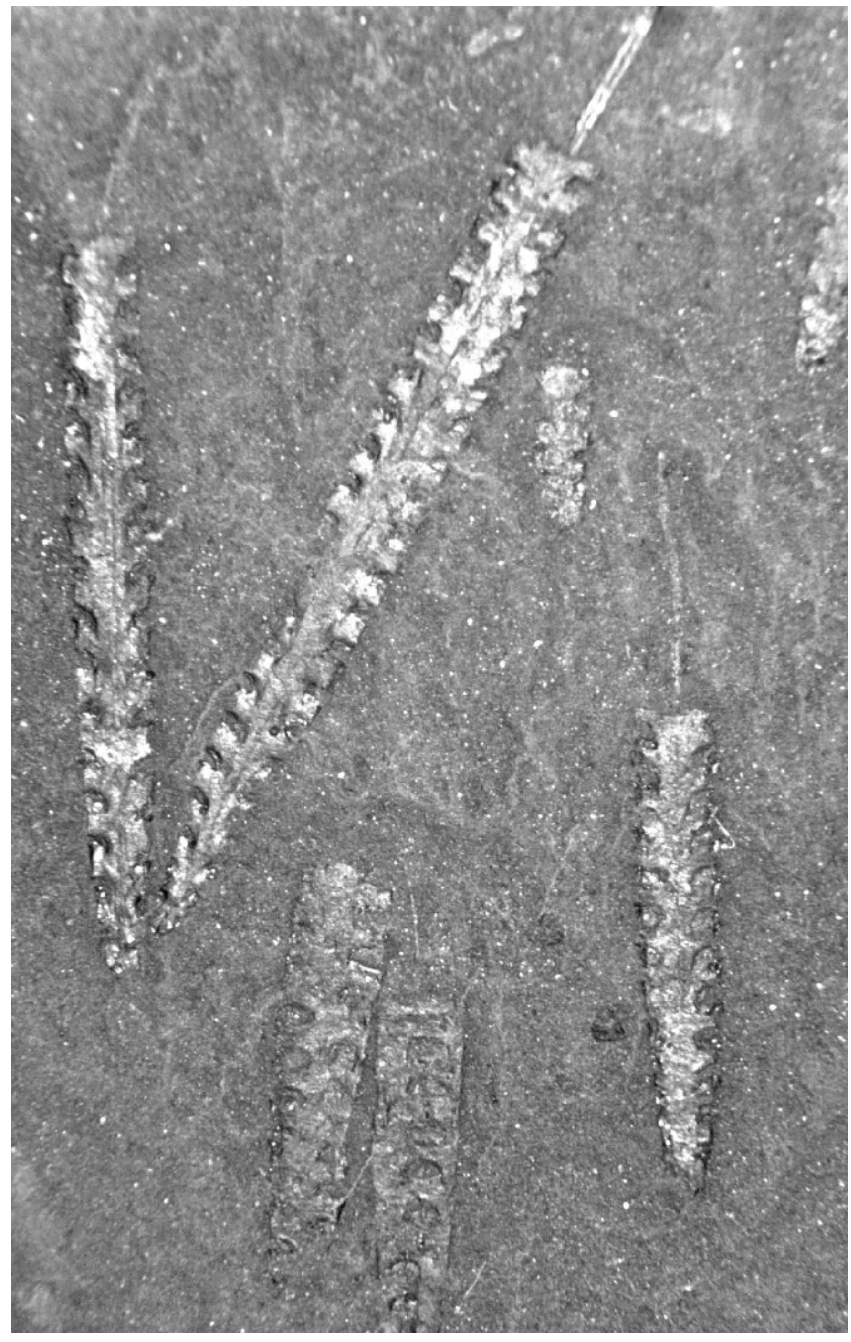

Fig. 13. Flow-aligned Normalograptus from the Neodiplograptus thuringiacus Biozone, Qusaiba Member, Saudi Arabia

The graptolite bottom right is $10 \mathrm{~mm}$ long (not including the nema)

confertus (Nicholson) s.l. and Neodiplograptus fezzanensis (Desio): the earliest occurrence of Glyptograptus tamariscus (Nicholson) s.l. is just below these three taxa in cores. The uppermost interval of this biozone probably overlaps with the lower part of the fezzanensis Biozone of Libya (see Štorch and Massa, 2006).

\section{CORONOGRAPTUS CYPHUS BIOZONE}

The cyphus Biozone was originally distinguished in the Rhayader area of central Wales by Lapworth (1900; see

). In Saudi Arabia the biozone is defined by the total range of Coronograptus cyphus (Lapworth). In Britain C. cyphus is known to occur in assemblages of the acinaces Biozone (Hutt and Rickards, 1970; Zalasiewicz et al., 2009: 829), equivalent to the upper part of the vesiculosus Biozone of Saudi Arabia. We have found C. cyphus to be a good marker for an interval between the ranges of $C$. vesiculosus and the earliest Demirastrites triangulatus s.I. in Saudi Arabia, and the species demarcates a similar interval in Bohemia (Štorch, 1994). In total, the cyphus Biozone yields about 20 graptolite taxa (Fig. 3A) including the earliest occurrences of Coronograptus gregarius (Lapworth), Glyptograptus sinuatus (Nicholson) s.l., and graptolites of the Monograptus revolutus group including Monograptus sudburiae Hutt. The biozone typically occupies only a very thin succession of black mudstones with a maximum thickness of $0.3 \mathrm{~m}$ and in many cores the cyphus Biozone is missing or unrecorded. The small thickness of the cyphus Biozone would likely preclude its recognition in most Arabian surface exposures. The cyphus Biozone of Saudi Arabia likely correlates with the upper part of the $N$. fezzanensis Biozone of Libya (Štorch and Massa, 2006) and approximately with the revolutus Biozone of Britain sensu Zalasiewicz et al. (2009).

\section{DEMIRASTRITES TRIANGULATUS BIOZONE}

The triangulatus Biozone represents the lowermost interval of the "Monograptus gregarius zone" of Lapworth (1878), later subdivided into triangulatus, magnus and leptotheca biozones (for history, see Sudbury, 1958; Zalasiewicz et al., 2009). In Saudi Arabia the triangulatus Biozone is characterized by 19 graptolite taxa (Fig. 3A) and is identified by the first occurrence of Demirastrites triangulatus (Harkness) s.l., which is abundant at some horizons, together with Pribylograptus incommodus (Törnquist) and "Paraclimacograptus" libycus (Desio). Rhaphidograptus toernquisti is commonly found. The base of the triangulatus Biozone and of the Aeronian Stage is often readily identifiable from this assemblage in the continuous core, even where the eponymous biozonal fossil is absent. The lower part of the biozone includes Demirastrites cf. triangulatus predecipiens Sudbury, while Rastrites longispinus Perner appears in the upper part. In some boreholes the thickness of the combined triangulatus and overlying thuringiacus biozones is $<1 \mathrm{~m}$, though the triangulatus Biozone more typically occupies a succession of about $2 \mathrm{~m}$ of black mudstones in Saudi Arabia. It is equivalent, at least in part, to the gregarius-libycus Biozone of Libya (Štorch and Massa, 2006) indicated by the first occurrence of " $P$." libycus at this level. While the gregarius-libycus Biozone assemblage is of low diversity in North Africa, in Saudi Arabia the triangulatus Biozone assemblage is diverse, possibly reflecting greater Silurian marine-shelf water-depths in the Arabian succession. The first occurrence of Demirastrites triangulatus s.I. and Rastrites at this level in Saudi Arabia also indicates correlation with the triangulatus Biozone in Britain (see Hutt, 1975).

\section{NEODIPLOGRAPTUS THURINGIACUS BIOZONE}

The thuringiacus Biozone takes its name from Neodiplograptus thuringiacus (Kirste) and this biostratigraphic interval appears to be equivalent to the magnus biozone of Britain, first recognized in the Rheidol Gorge of Wales by Jones (1909). In Saudi Arabia this biozone is characterized by 28 graptolite taxa (Fig. 3A, B), including the first definite occurrence of Neodipl. thuringiacus, and of Monograptus pseudoplanus Sudbury, and by abundant Monograptus sudburiae, Demirastrites triangulatus fimbriatus $(=D$. pectinatus of some authors) and Rhaphidograptus toernquisti. Above the base of the biozone the interval is associated with the earliest occurrences of retiolitids (possible Pseudoretiolites and petalolithids (Petalolithus ovatoelongatus (Kurck)), and with the incoming of the distinctive Pseudoglyptograptus barriei Zalasiewicz and Tunnicliff, possible Monograptus capis Hutt, and definitive Pseudorthograptus insectiformis (Nicholson). The top of the biozone is identified by the last occurrence of Demirastrites triangulatus s.l. The thuringiacus Biozone occupies a succession of strata between about 0.3 and $9 \mathrm{~m}$ thick in 
black graptolitic mudstones. As both " $P$." libycus and $C$. gregarius range through this interval, at least part of the thuringiacus Biozone of Saudi Arabia correlates with an interval in the upper part of the libycus-gregarius Biozone of Libya (Štorch and Massa, 2006). As strata bearing D. triangulatus fimbriatus are succeeded immediately in Saudi Arabia by those bearing Lituigraptus richteri (Perner) that denote the leptotheca Biozone, it is not certain whether an interval equivalent to the simulans Biozone - recognized in Bohemia (see Štorch, 1994) - may be differentiated in the Qusaiba Member.

\section{PRIBYLOGRAPTUS LEPTOTHECA BIOZONE}

This biozone was originally recognized in the English Lake District by Marr and Nicholson (1888) as the Monograptus argenteus Zone, named after one of its definitive species. Later Elles and Wood (1901-1918) noted the incoming of Pribylograptus leptotheca (Lapworth) at this level, a species that is more widely recorded than $M$. argenteus. In Saudi Arabia the leptotheca Biozone is characterized by 36 graptolite taxa, the base of the biozone being demarcated by the first occurrence of its two most distinctive species, Lituigraptus richteri and $P$. leptotheca (Fig. 3B). The leptotheca Biozone has a distinctive fauna that includes the first occurrences of an undescribed new species of Neolagarograptus, $N$. helenae (Štorch), Monograptus havliceki Štorch, M. imago Zalasiewicz, M. limatulus inopinus Törnquist, Campograptus clingani (Carruthers), C. lobiferus (McCoy), C. millepeda (McCoy), C. sanctgeorgensis Štorch and Petalolithus folium (Hisinger) (Fig. 3B). The top of the biozone is characterized by the last occurrence of $\mathrm{Li}$. richteri. The most commonly occurring taxon of the leptotheca Biozone is C. lobiferus, present in both low- and high-diversity assemblages. Based on the first occurrence of $P$. leptotheca this interval in Saudi Arabia is the equivalent of the leptotheca Biozone in Britain (Hutt, 1975; Zalasiewicz et al., 2009), but the Arabian assemblage shows the most striking similarity to the leptotheca assemblages of the Czech Republic described by Štorch (1998). The leptotheca Biozone of Saudi Arabia is probably equivalent to the "leptotheca" Biozone in Libya (Štorch and Massa, 2006), though in the latter area the biozone is characterized by a low-diversity assemblage that includes Neolagarograptus helenae (Štorch): we regard similar faunas as indicative of more shallow-water marine lithofacies in Saudi Arabia (see below). The leptotheca Biozone may occupy as little as $1 \mathrm{~m}$ of black graptolitic mudstone in Saudi Arabia, but can be expanded to $>40 \mathrm{~m}$ of strata.

\section{LITUIGRAPTUS CONVOLUTUS BIOZONE}

This biozone was originally recognized by Marr and Nicholson (1888) in the English Lake District and is equivalent to the "clingani Zone" and "cometa band" of Lapworth (1878). In Saudi Arabia the biozone yields over 30 graptolite taxa, many of them ranging from the preceding leptotheca Biozone (Fig. 3B). It is characterized by the first appearances of Lituigraptus convolutus (Hisinger), Torquigraptus decipiens (Törnquist), Monograptus limatulus limatulus Törnquist, Neolagarograptus impolitus Štorch, Rastrites hybridus Lapworth, Torquigraptus urceolinus (Stein), Rivagraptus bellulus (Törnquist), and Pristiograptus regularis (Törnquist). Paradiversograptus rectus (Manck) and Torquigraptus involutus (Lapworth) also have their first occurrences in this biozone, but above the base. Small fragments of $L i$. convolutus are often difficult to distinguish from Li. richteri in core material and in many instances the convolutus Biozone has been distinguished from the preceding leptotheca interval by the distinctive $T$. decipiens. Pribylograptus leptotheca ranges through much of this biozone, but disappears at a level approximately coincident with the incoming of Neolagarograptus rickardsi El Khayal, a species that informally identifies a discrete "rickardsi interval" in the uppermost convolutus Biozone. The neolagarograptids provide a subdivision more widely, as $N$. impolitus Štorch occurs in the lower part of the biozone, while $N$. tenuis (Portlock) appears just before the top of the biozone. This evolutionary lineage of Neolagarograptus is more useful here than the well-known succession of Cephalograptus species (Snelling et al., 2011), as the latter are rare in Saudi Arabia. The top of the convolutus Biozone seems generally coincident with the last occurrence of Li. convolutus, though the similar taxon, Lituigraptus urceolus (Richter) (distinguished by more closely spaced thecae), ranges up into the sedgwickii Biozone. At some levels, Normalograptus scalaris (Hisinger) dominates the assemblages.

Based on the first occurrences of $T$. decipiens and $L i$. convolutus, this interval is the stratigraphic equivalent of the convolutus Biozone in Libya (Štorch and Massa, 2006), the Czech Republic (Štorch, 1998) and Britain (Zalasiewicz et al., 2009). In some regions of Saudi Arabia thin rock successions bearing convolutus Biozone assemblages ( 3 to $4 \mathrm{~m}$ thick) sit unconformably atop Late Ordovician successions of the Sarah Formation. At its maximum extent, in deep-water graptolite shale facies, the convolutus Biozone occupies an interval of black mudstones that are more than $20 \mathrm{~m}$ thick.

\section{STIMULOGRAPTUS SEDGWICKII BIOZONE}

This biozone was distinguished by Lapworth (1878) in the Birkhill Shales Formation of southern Scotland and is typified by the first occurrence of Stimulograptus sedgwickii (Portlock). In Saudi Arabia the sedgwickii Biozone comprises about 19 taxa, mostly ranging from the preceding convolutus Biozone. The lowermost interval of the sedgwickii Biozone is characterized by Neolagarograptus tenuis (Portlock) that is characteristic of the $N$. tenuis assemblage Biozone in Libya (Štorch and Massa, 2006; see also Pannell et al., 2006): this interval also includes the first occurrence of Parapetalolithus altissimus (Elles and Wood). The earliest $N$. tenuis slightly precedes $S$. sedgwickii in Saudi Arabia, but the two graptolites overlap in the lower part of the biozone (through circa $4 \mathrm{~m}$ of stratigraphic thickness in one core). Cephalograptus cometa extrema Bouček and Přibyl, a taxon most often associated with the uppermost convolutus Biozone, occurs sporadically (and indeed, possibly ranges into the overlying halli Biozone). The sedgwickii Biozone occurs in a relatively narrow interval of typically 2 to $5 \mathrm{~m}$ of strata, but possibly as much as $8 \mathrm{~m}$ of black graptolitic mudstone in one core. It is a correlative of the lower part of the sedgwickii Biozone of Libya, including the tenuis interval (Štorch and Massa, 2006), but not of the whole of the Libyan interval that includes graptolites with a younger aspect (e.g., Pristiograptus cf. renaudi). The sedgwickii Biozone of Saudi Arabia is the correlative of the same biozone in Britain (Zalasiewicz et al., 2009).

\section{STIMULOGRAPTUS HALLI BIOZONE}

The halli Biozone was recognized in Wales by Jones and Pugh (1916) and revitalized by the studies of Loydell (1991, 1992, 1993). The nominate species of the biozone, Stimulograptus halli (Barrande), is distinguished from the contemporaneous S. sedgwickii by its broader dorso-ventral width (see Loydell, 1993), though in practice the dimensions of halli 
and sedgwickii overlap (see discussion of the history of this biozone in Zalasiewicz et al., 2009). The halli Biozone represents a distinctive interval in Saudi Arabia characterized by 25 taxa, and associated with the first definitive occurrence of Oktavites contortus (Perner), and of Comograptus barbatus (Elles and Wood), Rastrites schaueri Štorch and Loydell, $R$. linnaei Barrande, R. gracilis Pribyl, Streptograptus ansulosus (Törnquist) and Torquigraptus linterni Williams et al. (see Fig. 3C). These indicate its correlation with the halli Biozone of Britain. There is a distinct upper part of the biozone in Saudi Arabia, probably reflecting an interval which is commonly barren of graptolites elsewhere, and which includes the Aeronian-Telychian boundary (see also Štorch and Fryda, 2012). It includes taxa such as "Spirograptus" andrewsi (Sherwin) and possible Lituigraptus rastrum (Richter), though assemblages are commonly of low diversity, with swarms of $S$. ansulosus being locally common. Further study of this interval could provide a clearer definition of the Aeronian-Telychian boundary, particularly given the problems with the boundary stratotype clearly demonstrated by Davies et al. (2013). The halli Biozone assemblage of graptolites has not been recorded from Libya (Štorch and Massa, 2006), and the halli Biozone probably equates to an unspecified interval in the upper part of the sedgwickii Biozone there. The first occurrence of $R$. linnaei in the halli Biozone indicates that this level in Saudi Arabia equates to the lower part of the linnaei Biozone of the Czech Republic (Štorch and Loydell, 1992). The halli Biozone is present through up to $7 \mathrm{~m}$ of black graptolitic mudstones in Saudi Arabia.

\section{SPIROGRAPTUS GUERICHI BIOZONE}

The guerichi Biozone was defined by Loydell et al. (1993) and represents the lower part of the turriculatus Biozone s.l. of former usage (see for e.g., Rickards, 1976). In Saudi Arabia the biozone contains over 40 taxa and is identified by the incoming of Spirograptus guerichi Loydell, Štorch and Melchin (Fig. 3C). The top of the biozone is uncertain in Saudi Arabia, as the biozonal fossil of the succeeding turriculatus Biozone has not been recorded in the Qusaiba Member. In Wales the guerich Biozone has been subdivided into four subzones: the runcinatus, gemmatus and renaudi subzones, and the lower part of the utilis Subzone (Loydell, 1992, 1993). We do not recognize a separate runcinatus Biozone in Saudi Arabia, as taxa typical of the gemmatus Biozone (Monograptus gemmatus (Barrande) itself, Glyptograptus fastigatus Haberfelner, Pristiograptus renaudi (Philippot), and Streptograptus pankhurstae (Sherwin) soon succeed a low-diversity and regionally variable unit up to $5 \mathrm{~m}$ thick that seems mostly assignable to the underlying halli Biozone. Some of these graptolites seem to precede the appearance of Spirograptus guerichi itself, though this needs further study, as S. guerichi is sporadic in its distribution early in its range. The total thickness of strata in which the guerichi Biozone is developed exceeds $30 \mathrm{~m}$ of black mudstone in the continuous core.

The guerichi Biozone of Saudi Arabia records essentially the same succession of graptolites, and is an equivalent of the guerichi Biozone in Britain. The overall suite of graptolites, and the common occurrence of Rastrites linnaei Barrande and $R$. maximus Carruthers through this interval, also indicate equivalence to the middle and upper part of the linnaei Biozone in the Czech succession (Štorch and Loydell, 1992).

Monograptus gemmatus Subzone. In Saudi Arabia this subzone is distinguished by the total range of Monograptus gemmatus. In continuous core the base of this interval is recognized by the first occurrence of the characteristic early
Telychian Monograptus bjerreskovae Loydell, the most common species at this level, and by Glyptograptus fastigatus. The gemmatus Subzone is also characterized by the first occurrence of a suite of Streptograptus species (Fig. 3C), including S. plumosus (Baily), S. strachani Loydell and S. filiformis Chen, while another distinctive member of this assemblage is Streptograptus pankhurstae. The top of the subzone is defined as the interval immediately preceding the first occurrence of a suite of robust Parapetalolithus graptolites that define the base of the succeeding renaudi Subzone. In practice the sub-zonal boundary is often difficult to establish, as $M$. gemmatus is rare in its upper range.

Pristiograptus renaudi Subzone. This subzone is often difficult to recognize in cores, as the nominate species, $P$. renaudi, is long-ranging from the earliest Telychian. The first occurrences of Rastrites fugax Barrande and Streptograptus storchi Loydell equate to a level in the uppermost gemmatus Subzone or lower renaudi Subzone. Decisive indication of the renaudi Subzone is given by Parapetalolithus elongatus (Bouček and Přibyl), Parapetalolithus conicus (Bouček), and Parapetalolithus giganteus (Bouček and Pribyl), in tandem with abundant $P$. renaudi. The upper part of the subzone is characterized by Torquigraptus cavei Loydell.

Stimulograptus utilis Subzone (lower part). This subzone is only tentatively identified in Saudi Arabia, based on the occurrence of Pristiograptus cf. bjerringus (Bjerreskov) at two horizons in one core, co-occurring with Stimulograptus becki (Barrande) and Spirograptus guerichi: P. cf. bjerringus succeeds an interval with $P$. giganteus and $T$. cavei that is typical of the upper renaudi Subzone. In Spain, $P$. bjerringus is known from the palmeus Subzone (Guitiérrez-Marco and Štorch, 1998) that probably correlates to the same stratigraphical level as the renaudi Subzone.

\section{REGIONAL SIGNIFICANCE OF THE SAUDI ARABIAN GRAPTOLITE BIOZONATION}

Correlation of the graptolite biozonation for the Early Silurian of Saudi Arabia with the biozonal schemes in North Africa, the Czech Republic and the UK is shown in Figure 14. Differences in the ranges of individual taxa between regions have been noted in the discussion of the biozones above. Here we comment on differences in the definition of particular intervals of the Arabian biozonal scheme where they are important for interregional correlation.

\section{CORRELATION OF THE ASCENSUS-ACUMINATUS} AND VESICULOSUS BIOZONES

The earliest N. Iubricus Biozone interval of Saudi Arabia appears equivalent to the locally distinguished lubricus Subzone of Uzbekistan, the lowermost interval of the ascensus-acuminatus Biozone as defined there (Koren' and Melchin, 2000). In Saudi Arabia the succession of graptolites in the early Rhuddanian is essentially comparable with that recognized in peri-Gondwanan Europe and Jordan (see Štorch, 1996; Loydell, 2007), there being an early ascensus-acuminatus Biozone characterized by abundant Akidograptus ascensus, while Normalograptus trifilis and abundant Parakidograptus acuminatus appear at younger levels in the biozone. The base of the succeeding vesiculosus Biozone is here taken at the first appearance of the eponymous species, as generally elsewhere (Štorch, 1994: fig. 2): overlapping ranges for $P$. acuminatus and Cystograptus vesiculosus are not recorded in Saudi Arabia (cf. Štorch, 1996). 


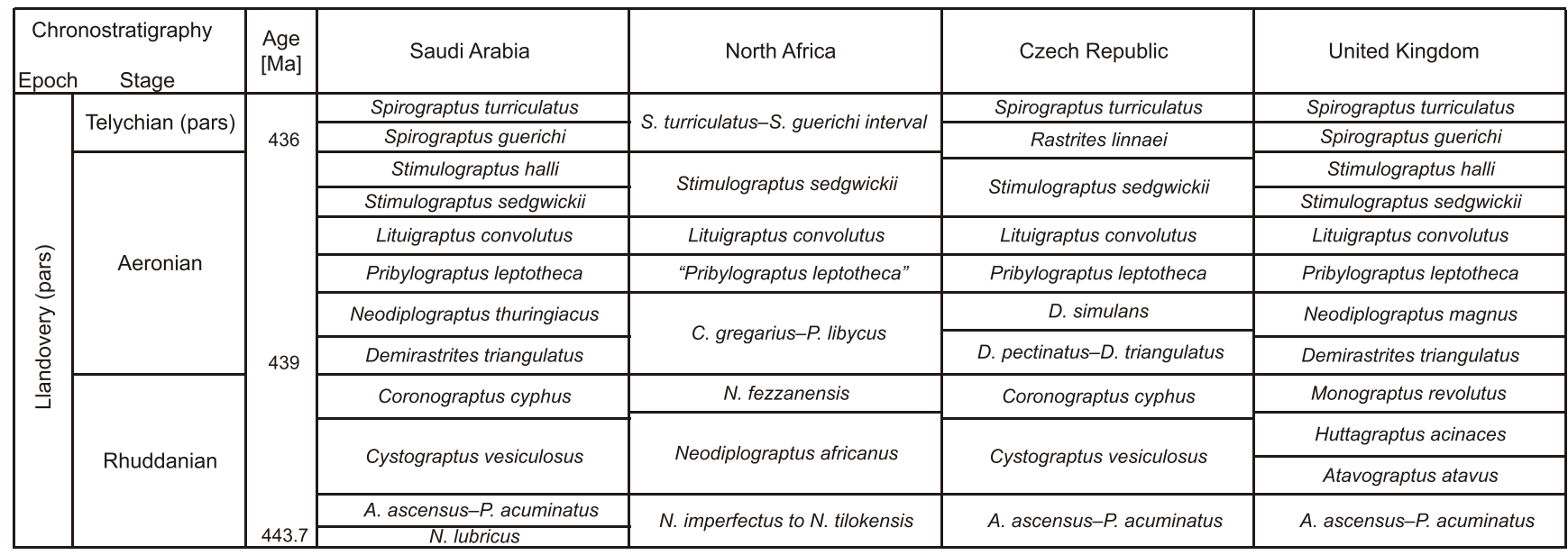

Fig. 14. Correlation of graptolite biozones for the Early Silurian (Llandovery) of Saudi Arabia with the graptolite biozonal schemes in North Africa (Libya, Štorch and Massa, 2006), United Kingdom (Zalasiewicz et al., 2009), and the Czech Republic (Štorch, 1994, 1996); data are also compiled from Loydell (2012)

CORRELATION OF THE FEZZANENSIS BIOZONE OF NORTH AFRICA

The graptolite assemblages of Saudi Arabia contain Neodiplograptus fezzanensis from the upper part of the vesiculosus Biozone, co-occurring with the earliest Rhaphidograptus toernquisti, Metaclimacograptus undulatus and Glyptograptus tamariscus. N. fezzanensis is widespread, occurring in the succession of North Africa (e.g., Legrand, 1979) and Central Europe (Štorch, 1996). Occurrence of $N$. fezzanensis within the vesiculosus Biozone suggests that in part, the fezzanensis Biozone of North Africa (see Štorch and Massa, 2006) correlates with the upper vesiculosus Biozone (Fig. 14). Štorch and Massa (2006) recorded N. fezzanensis with graptolites of the cyphus Biozone, though this has not been replicated in Saudi Arabia, and they considered the total range of $N$. fezzanensis to extend into the earliest Aeronian.

\section{SUBDIVISION AND CORRELATION OF THE SEDGWICKII BIOZONE}

Pannell et al. (2006) identified a discrete stratigraphical interval at the base of the sedgwickii Biozone in Scotland that was characterized by several peaks of abundance of Neolagarograptus tenuis. They suggested that these peaks might represent widely correlatable events. Elsewhere the interval of the lower sedgwickii Biozone has been identified as a discrete tenuis Subzone that is characterized by the abundance of the eponymous species, and which is recognized in Bohemia and North Africa (Štorch and Massa, 2006), and also in the lower part of the sedgwickii Biozone in Saudi Arabia. Pannell et al. (2006) suggested that this interval represented about $0.2 \mathrm{Ma}$, being of comparable duration to the subzones of the Telychian guerichi Biozone. This provides a highly resolved stratigraphy that allows correlation from palaeocontinental Gondwana at high southern palaeo-latitude to palaeocontinental Laurentia in the palaeo-tropics.

\section{CORRELATION OF THE EARLY TELYCHIAN}

The guerichi Biozone of the early Telychian is well-developed in Saudi Arabia, the interval being characterized by the common occurrence of the biozonal index species Spirograptus guerichi. This graptolite occurs in strata succeeding those of a well-defined halli Biozone that indicate its correlation with the guerichi Biozone of Wales (see Loydell, 1991, 1992, 1993). Strata bearing S. guerichi in Saudi Arabia succeed those with the earliest Rastrites linnaei, providing correlation with successions in continental Europe that identify a linnaei Biozone at this stratigraphic level (see Štorch and Loydell, 1992; Gutiérrez-Marco and Štorch, 1998). The lowermost part of the guerichi Biozone in Saudi Arabia does not usually bear the subzonal index fossil Paradiversograptus runcinatus (Lapworth). P. runcinatus has been found in low-diversity assemblages in lithofacies that seem to represent more inshore conditions. P. runcinatus is known from Wales (Loydell 1993), though Gutiérrez-Marco and Štorch (1998) noted the rarity of this graptolite in the Spanish succession, and chose to identify a combined runcinatus-gemmatus Subzone as the lowermost interval of the linnaei Biozone. We suggest that part of the low-diversity interval at the base of the guerichi Biozone in Saudi Arabia may equate to the runcinatus Subzone in Wales; in both areas it is succeeded by rocks that bear abundant Monograptus gemmatus, with this graptolite effecting a clear subzonal correlation between the Welsh and Arabian successions. Above the gemmatus Subzone in Saudi Arabia the renaudi Subzone can be recognized and this is probably an equivalent biostratigraphic level to the eponymous subzone in Wales (Loydell, 1992). As the renaudi Subzone in Saudi Arabia also contains Parapetalolithus elongatus, this suggests correlation with the palmeus Subzone of the linnaei Biozone in Spain (Gutiérrez-Marco and Štorch, 1998).

\section{GRAPTOLITE BIOTOPES}

Analysis of the temporal and spatial distribution of the graptolites in over 130 cores from Saudi Arabia identifies a persistent pattern of Llandovery age depth-stratified marine assemblages. These have been interpreted from their associated fauna and lithofacies and from knowledge of palaeo-basin bathymetry (Konert et al., 2001). These distribution patterns resemble those synthesized for Ordovician graptolites by Cooper 
and Sadler (2010 and references therein), who identified a surface-dwelling biotope occupying the euphotic zone of Ordovician oceans, analogous to the mixed layer of modern oceans, and, a deeper water biotope the distribution of which may have been controlled by oxygen-level and food supply, occupying the oxygen-minimum zone of Ordovician oceans, and bearing the typical assemblages of graptolitic black mudstones.

In general, boreholes from north-west Saudi Arabia (Fig. 2) penetrate black shale successions that record continuous deposition on a distal marine shelf, through several graptolite biozones. These cores preserve little evidence of burrowing benthos, or of shelly fauna. Typical associates of the graptolites are orthoconic nautiloids and small (pseudoplanktonic?) lingulate brachiopods. The graptolites in these marine settings are typically high-diversity assemblages, sometimes reaching 15 species on a single lamination surface in core. In the Aeronian and Telychian such assemblages are characterized by spirally and helically coiled species of Lituigraptus (Li. richteri and $L i$. convolutus), Torquigraptus ( $T$. involutus, T. linterni), Spirograptus ( $S$. guerichi) and Rastrites ( $R$. linnaei, $R$. maximus). Graptolites of this assemblage are not found in more near-shore facies, or in regions of elevated basin topography where seawater depth shoaled.

Graptolites of a low-diversity, presumed surface-dwelling graptolite biotope are preserved with their deep-water counterparts in deep basin settings. That they were near-surface dwellers is suggested by their presence in more near-shore shelf environments of central and eastern Saudi Arabia, where a range of sand-dominated successions indicates the influence of prograding deltas active from the Early Silurian. They are preserved with an extensive benthic faunal assemblage (including trilobites, bivalves, brachiopods, burrows) on topographic highs within deeper basin settings in the northwestern area, where they can be used to determine palaeo-basin topography. These shallow biotope graptolites typically comprise species of Normalograptus, Neodiplograptus (N. fezzanensis), Stimulograptus (e.g., S. sedgwickii, S. becki), Neolagarograptus and Coronograptus (especially C. gregarius), with a di- versity of generally one or two taxa at each horizon. Štorch and Massa (2006) have described similar assemblages from North Africa, contrasting these with the more richly diverse assemblages of peri-Gondwanan Europe. Graptolites of the presumed surface-dwelling biotope are often present as flow-aligned assemblages on lamination surfaces, presumably deposited from turbidity or storm-driven currents that formed on the shelf, transporting the graptolites basin-wards (Fig. 13).

Cooper and Sadler (2010) noted the overall stability of the surface-dwelling epipelagic graptolite biotope and its lower susceptibility to environmental perturbation from climatically induced changes to ocean circulation. By contrast, they noted that the deep-water biotope was susceptible to change, being widespread in stratified oceans during greenhouse climates, but disrupted by a thermohaline circulation during icehouse climate states. They noted the temporal longevity of taxa from the surface epipelagic biotope and equated this to environmental stability, a pattern that may also be present in some of the Silurian graptolites. Thus, graptolites of the surface-dwelling biotope recognized in Saudi Arabia include the long-lived Coronograptus gregarius (spanning five graptolite biozones), "Paraclimacograptus" libycus (spanning four), and Stimulograptus sedgwickii (spanning three). This biotope also contains short-lived, but closely related Neolagarograptus species such as $N$. rickardsi and $N$. tenuis.

\section{GRAPTOLITE BIOGEOGRAPHY}

Here we compare the biogeographical signature of the Saudi Arabian graptolites with contemporaneous faunas in North Africa, continental Europe and the UK. These areas represent palaeogeographical entities that were Gondwanan and peri-Gondwanan (e.g., the Perunica micro-continent for Bohemia), Avalonian and Laurentian, and which provide a latitudinal gradient from the southern high palaeo-latitudes to the palaeo-tropics (Fig. 15): this distribution can be used to assess some of the possible environmental and geographical control

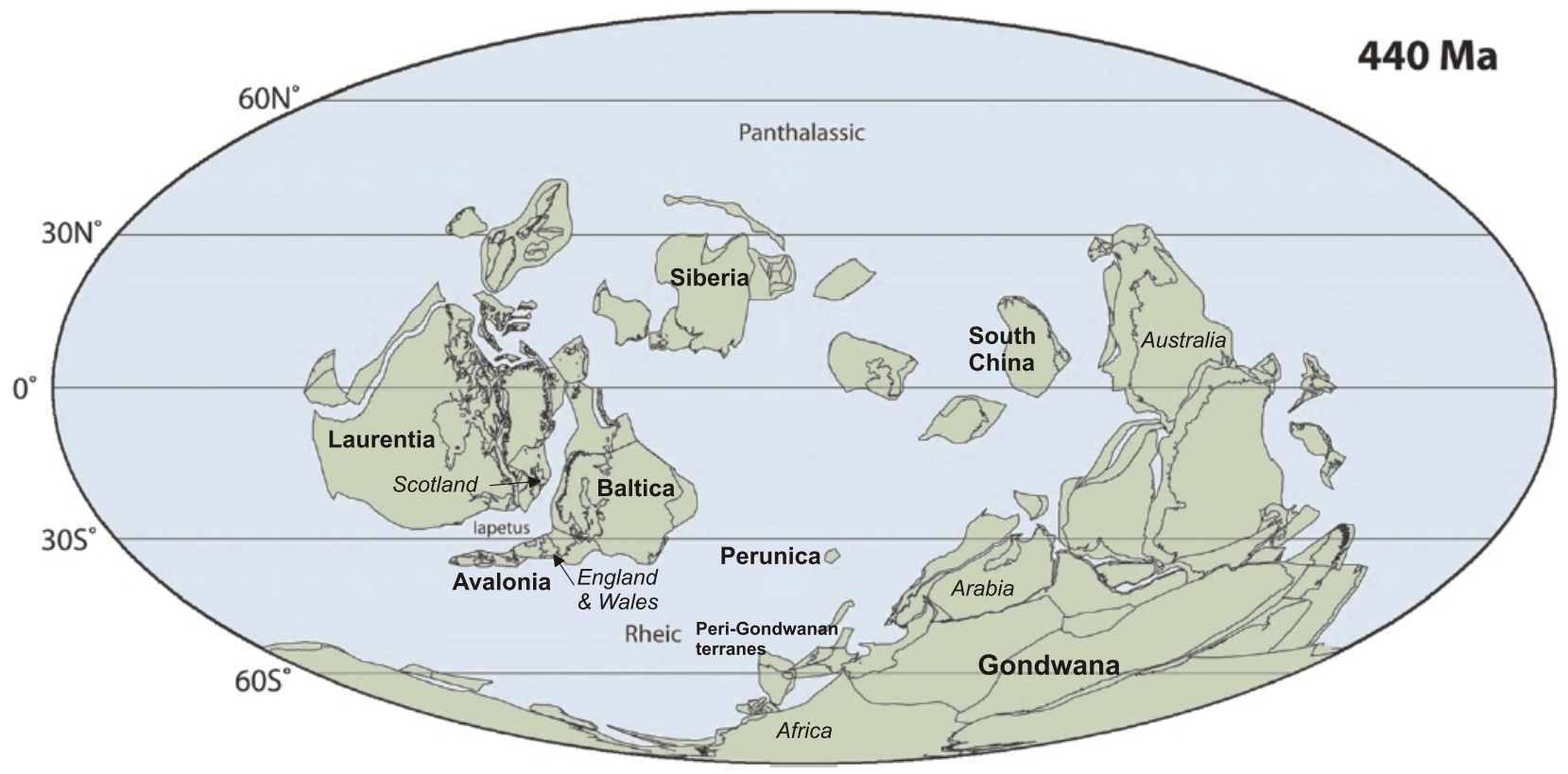

Figure 15. Early Silurian (Llandovery) palaeogeography (base map from Torsvik and Cocks, 2013)

Palaeocontinents are labelled in bold. Geographical areas are labelled in italics. The lapetus, Rheic and Panthalassic oceans are also marked. Peri-Gondwanan terranes include Iberia, Armorica, Saxo-Thuringia and Perunica 
mechanisms on graptolite distribution. During the Silurian, Gondwana formed a large southerly landmass composed of Africa, South America, India, Australia, Antarctica and the Arabian Peninsula. This supercontinent straddled the palaeogeographical South Pole, but extended into mid-latitudes (Fig. 15): Saudi Arabia was situated at mid southern palaeo-latitude, between $30^{\circ}$ to $50^{\circ} \mathrm{S}$.

The early Rhuddanian graptolites of Saudi Arabia show a remarkably similar biogeographical motif to assemblages of peri-Gondwanan Europe (see Štorch, 1996). Especially at the level of the ascensus-acuminatus Biozone, these assemblages are often dominated by large Neodiplograptus species, particularly $N$. parajanus, $N$. africanus, $N$. lanceolatus and $N$. cf. apographon. Graptolites of this assemblage are well-documented from Jordan (Loydell, 2007), Spain, Germany, Austria and Bohemia (Štorch 1996: fig. 5). But, they are absent from the early Rhuddanian graptolite assemblages of Britain (e.g. Toghill, 1968; Zalasiewicz and Tunnicliff, 1994). Nevertheless, much of the graptolite fauna of the lowermost Rhuddanian in Saudi Arabia comprises taxa that occur also at lower palaeo-latitudes, including Akidograptus ascensus, Normalograptus? parvulus, Normalograptus trifilis and Parakidograptus acuminatus. These graptolites are used to zone the same interval in the Southern Uplands of Scotland, and therefore occupied the southern, ocean-facing margin of palaeo-tropical Laurentia (Fig. 15). Either these graptolites were deep-water forms whose distribution was not controlled by the surface-water temperature gradient; or they were eurythermic and not affected by this gradient; or, there was a low thermal gradient from the tropics to the poles in the deglacial interval following the Hirnantian icehouse. The latter scenario seems unlikely, as the distinct high to mid latitude Neodiplograptus-dominated assemblage present in Saudi Arabia and peri-Gondwanan Europe suggests a cool water surface assemblage adapted for these palaeo-latitudes, and this is not present at (warmer?) lower latitudes. Štorch (1996) has discussed distinct differences between the Gondwanan assemblages of the ascensus-acuminatus Biozone and other palaeogeographical entities including South China, Siberia and Kazakhstan, noting for example the abundance of metaclimacograptids in the assemblages of the Gorny Altai.

The persistence of a distinctive Gondwanan fauna in Saudi Arabia continues into the vesiculosus and cyphus biozones and is typified by Neodiplograptus fezzanensis, and in the early to mid Aeronian by "Paraclimacograptus" libycus. Nevertheless, this high latitude fauna is associated with post-ascensus-acuminatus cosmopolitan graptolites, that include at the level of the vesiculosus Biozone the pan-latitude species Cystograptus vesiculosus, Rhaphidograptus toernquisti and Metaclimacograptus undulatus, and in the cyphus Biozone, Coronograptus cyphus, C. gregarius and the revolutus-group monograptids. Distinctive Saudi Arabian faunas can still be identified within the Aeronian, and include at the level of the leptotheca Biozone an undescribed (apparently new) Neolagarograptus species. Biogeographical differences are also exemplified by the absence of Campograptus harpago (Törnquist) from Saudi Arabia (see Chopey-Jones et al., 2003: fig. 5) a taxon thought to characterize mid-latitude regions at this time. Nevertheless, much of the mid-Aeronian graptolite fauna of Saudi Arabia is indistinguishable at the species-level from the contemporaneous faunas of Bohemia (Štorch, 1994), Wales (e.g., Zalasiewicz, 1996) and Scotland (e.g., Chopey-Jones et al., 2003).

The incoming of Neolagarograptus tenuis characterizes the beginning of a late Aeronian and early Telychian interval in Saudi Arabia that is essentially composed of cosmopolitan taxa, which also occur at lower palaeo-latitude. Thus, the Saudi Arabian graptolite assemblage of the sedgwickii Biozone contains species that are also present in southern Scotland (Pannell et al., 2006; Williams et al., 2003), England (e.g., Hutt, 1975), Wales (Loydell, 1992, 1993) and Bohemia (Štorch, 1994). This pattern continues into the halli and guerichi biozones, enabling sub-zonal correlation between Wales and Saudi Arabia. More inshore shelf depositional successions in Saudi Arabia do not record graptolites in the sedgwickii Biozone (Zalasiewicz et al., 2007; Page et al., 2007), but this is not reflected in the continuous depositional successions of distal shelf settings in north-west Saudi Arabia where the sedgwickil Biozone is richly fossiliferous and contiguous with preceding convolutus and succeeding halli intervals. This adds weight to the suggestion of Loydell (1998: 454) that the lack of sedgwickii Biozone faunas in some areas (e.g., Bornholm, palaeocontinental Baltica, see Bjerreskov, 1975) may not represent a global sea level fall in the earliest sedgwickii Biozone, and this is counter to the idea of a sedgwickii Biozone glaciation (cf. Page et al., 2007). Instead, the absence of sedgwickii Biozone faunas from some areas may relate to local basin evolution. In Wales, as in Saudi Arabia, the sedgwickii Biozone is partly in black shales and is graptolitic (Zalasiewicz, 1990). But, the sedgwickii-bearing succession in Wales probably represents only part of the sedgwickii Biozone, with much of the rock interval in oxic, grey mudstones.

\section{CONCLUSIONS}

Analysis of graptolites from the Qusaiba Member, Qalibah Formation of Saudi Arabia, provides a refined graptolite biostratigraphy for the Arabian Peninsula. Over 150 graptolite species characterize 11 biozones from the base of the Llandovery to the lower Telychian guerichi Biozone. Graptolite spatial distribution suggests persistent depth-stratified assemblages, with low-diversity surface-dwelling assemblages characterized by species of Neodiplograptus, Coronograptus, Neolagarograptus and Stimulograptus, and higher diversity (up to 15 species per horizon), deeper marine assemblages typified by dorsally curved and helically coiled species of Spirograptus, Demirastrites, Lituigraptus, Rastrites and Torquigraptus. Biogeographically, the graptolite assemblages of Saudi Arabia are remarkably similar to contemporaneous faunas from peri-Gondwanan Europe and, from the mid-Rhuddanian onwards, with Avalonian and Laurentian faunas.

Acknowledgements. We are grateful to the Saudi Ministry of Petroleum Resources and the Saudi Arabian Oil Company (Saudi Aramco) for permission to publish this work. We also thank N. Hooker (Saudi Aramco) for continuous support in facilitating this study. We are grateful for detailed comments on drafts of this manuscript from D. Loydell, M. Howe, M. Miller, T. Podhalańska, A. Kozłowska and T.M. Peryt. 


\section{REFERENCES}

Bjerreskov, M., 1975. Llandoverian and Wenlockian graptolites from Bornholm. Fossils and Strata, 8: 1-94.

Chopey-Jones, A., Williams, M., Zalasiewicz, J.A., 2003 Biostratigraphy, palaeobiogeography and morphology of the Llandovery graptolites Campograptus lobiferus (M'Coy) and Campograptus harpago (Törnquist). Scottish Journal of Geology, 39: 71-85.

Cooper, R.A., Sadler, P.M., 2010. Facies preference predicts extinction risk in Ordovician graptolites. Paleobiology, 36: 167-187.

Davies, J.R., Waters, R.A., Molyneux, S.G., Williams, M., Zalasiewicz, J.A., Vandenbroucke, T.R.A., Verniers, J., 2013. A revised sedimentary and biostratigraphical architecture for the Type Llandovery area, Central Wales. Geological Magazine, 150: 300-332.

El-Khayal, A.A., 1985. Some Silurian (Llandovery) monograptids from Saudi Arabia. Scripta Geologia, 80: 15-22.

El-Khayal, A.A., 1986. Petalograptus palmeus Barrande from the Qusayba Shale (Llandovery, Silurian) of Saudi Arabia. Journal of the College of Science, King Saud University, 17: 189-206.

El-Khayal, A.A., 1987a. Silurian graptolites from the Qusayba Shale (Llandovery) of central Saudi Arabia. Bulletin of the Geological Society of Denmark, 35: 125-133.

El-Khayal, A.A., 1987b. The genus Pristiograptus in the Silurian rocks (Llandoverian) of Saudi Arabia. Journal of the University of Kuwait (Science), 14: 385-392.

El-Khayal, A.A., 1987c. Lagarograptus rickardsi sp. nov from the Silurian (Llandovery) of Saudi Arabia. Journal of the College of Science, King Saud University, 18: 139-146.

Elles, G.L., Wood, E.M.R., 1901-1918. A monograph of British graptolites. The Palaeontographical Society, London.

Gutiérrez-Marco, J.C., Štorch, P., 1998. Graptolite biostratigraphy of the Lower Silurian (Llandovery) shelf deposits of the Western Iberian Cordillera, Spain. Geological Magazine, 135: 71-92.

Hutt, J.E., 1974. The Llandovery graptolites of the English Lake District. The Palaeontographical Society, London. Publication 540, part of volume 128: 1-56.

Hutt, J.E., 1975. The Llandovery graptolites of the English Lake District. The Palaeontographical Society, London. Publication 542, part of volume 129: 57-137.

Hutt, J.E., Rickards, R.B., 1970. The evolution of the earliest Llandovery monograptids. Geological Magazine, 107: 67-77.

Janjou, D., Halawani, M.A., Al-Muallem, M.S., Robelin, C. Brosse, J.-M., Courbouleix, S., Dagain, J., Genna, A., Razin, P., Roobol, M.J., Shorbaji, H., Wyns, R., 1996. Geologic Map of the Al Qalibah Quadrangle, Sheet 28 C, Kingdom of Saudi Arabia. Saudi Arabian Deputy Ministry for Mineral Resources, Geoscience Map Series GM-135, scale 1:250,000, with text, 44 pp.

Jones, O.T., 1909. The Hartfell-Valentian succession in the district around Plynlimon and Pont Erwyd (North Cardiganshire). Quarterly Journal of the Geological Society of London, 65: 463-537.

Jones, O.T., Pugh, W.J., 1935. The geology of the districts around Machynlleth and Aberystwyth. Proceedings of the Geologists Association, 46: 247-300.

Jones, P.J., Stump, T.E. 1999. Depositional and tectonic setting of the Lower Silurian hydrocarbon source rock facies, Central Saudi Arabia. AAPG Bulletin, 83: 314-332

Konert, G., Afifi, A.M., Al-Hajri, S., Droste, H.J., 2001. Paleozoic stratigraphy and hydrocarbon habitat of the Arabian Plate. GeoArabia, 6: 407-442.

Koren', T.N., Bjerreskov, M., 1997. Early Llandovery monograptids from Bornholm and the southern Urals: taxonomy and evolution. Bulletin of the Geological Society of Denmark, 44: 1-43.

Koren', T.N., Melchin, M., 2000. Lowermost Silurian graptolites from the Kurama Range, eastern Uzbekistan. Journal of Paleontology, 74: 1093-1113.
Lapworth, C., 1878. The Moffat Series. Quarterly Journal of the Geological Society of London, 34: 240-346.

Lapworth, H., 1900. The Silurian sequence of Rhayader. Quarterly Journal of the Geological Society of London, 56: 67-137.

Legrand, P., 1979. Premières observations sur des structures tubulaires à l'intérieur des thèques de Diplograptus fezzanensis Desio. Essai d'interpretation. Acta Palaeontologica Polonica, 24: $107-120$

Loydell, D.K., 1991. The biostratigraphy and formational relationships of the upper Aeronian and lower Telychian (Llandovery, Silurian) formations of western mid-Wales. Geological Journal, 26: 209-44.

Loydell, D.K., 1992. Upper Aeronian and lower Telychian (Llandovery) graptolites from western mid-Wales. London: The Palaeontographical Society. Publication 589 for volume 146: $1-55$.

Loydell, D.K., 1993. Upper Aeronian and lower Telychian (Llandovery) graptolites from western mid- Wales. London: The Palaeontographical Society. Publication 592 for volume 147: 56-180.

Loydell, D.K., 1998. Early Silurian sea-level changes. Geological Magazine, 135: 447-471.

Loydell, D.K., 2007. Graptolites from the Upper Ordovician and Lower Silurian of Jordan. Special Papers in Palaeontology, 78: $1-66$.

Loydell, D.K., 2012. Graptolite biozone correlation charts. Geological Magazine, 149: 124-132.

Loydell, D.K., Štorch, P., Melchin, M.J., 1993. Taxonomy, evolution and biostratigraphical importance of the Llandovery graptolite Spirograptus. Palaeontology, 36: 909-26.

Mahmoud, M.D., Vaslet, D., Husseini, M.I., 1992. The Lower Silurian Qalibah Formation of Saudi Arabia: an important hydrocarbon source rock. AAPG Bulletin, 76: 1491-1506.

Marr, J.E., Nicholson, H.A., 1888. The Stockdale Shales. Quarterly Journal of the Geological Society of London, 44: 654-732.

McClure, H.A., 1988. The Ordovician-Silurian boundary in Saudi Arabia. Bulletin of the British Museum of Natural History (Geology), 43: 155-163.

Miller, M., Melvin, J., 2005. Significant new biostratigraphic horizons in the Qusaiba member of the Silurian Qalibah Formation of central Saudi Arabia, and their sedimentologic expression in a sequence stratigraphic context. GeoArabia, 10: 50-92.

Miller, M., Al-Ruwaili, M., 2007. Preliminary palynological investigation of Saudi Arabian Upper Ordovician glacial sediments. Revue de Micropaléontologie, 50: 17-26.

Nicholson, H.A., 1868. On the graptolites of the Coniston Flags. Quarterly Journal of the Geological Society of London, 24: $521-45$.

Page, A., Zalasiewicz, J.A., Williams, M., Popov, L.E., 2007. Were transgressive black shales a negative feedback modulating glacioeustasy in the Early Palaeozoic Icehouse? In: Deep-Time Perspectives on Climate Change: Marrying the Signal from Computer Models and Biological Proxies (eds. M. Williams, A.M. Haywood, F.J. Gregory and D.N. Schmidt): 123-156. The Micropalaeontological Society, Special Publications. The Geological Society, London.

Pannell, C.L., Clarkson, E.N.K., Zalasiewicz, J.A., 2006. Fine-scale biostratigraphy within the Stimulograptus sedgwickii Biozone (Llandovery: Silurian) at Dob's Linn, Southern Uplands. Scottish Journal of Geology, 42: 59-64.

Rickards, R.B., 1976. The sequence of Silurian graptolite zones in the British Isles. Geological Journal, 11: 153- 88.

Rickards, R.B., Koren', T.M. 1974. Virgellar meshworks and sicular spinosity in Llandovery graptoloids. Geological Magazine, 111: 193-204.

Senalp, M. 2006. Stratigraphy and sedimentology of the Paleozoic successions in Saudi Arabia. Unpublished Aramco Internal Report. 
Senalp, M., Al-Ruwaili, M.H., Miller, M.A., 2002. New evidence on the stratigraphy of the Ordovician-Silurian boundary in Saudi Arabia. GeoArabia, 7: 298-299.

Sharland, P.R., Archer, R., Casey, D.N., Davies, R.B., Hall, S.H., Heward, A.P., Horbury, A.D., Simmons, M.D., 2001. Arabian Plate Sequence Stratigraphy. GeoArabia Special Publication 2, Gulf PetroLink, Bahrain.

Snelling, A.M., Bates, D.E.B., Zalasiewicz, J.A., 2011. Graptolite studies in honour of Barrie Rickards (1938-2009). Proceedings of the Yorkshire Geological Society, 58: 208-356.

Štorch, P., 1994. Graptolite biostratigraphy of the Lower Silurian (Llandovery and Wenlock) of Bohemia. Geological Journal, 29 137-65.

Štorch, P., 1996. Basal Silurian Akidograptus ascensus-Parakidograptus acuminatus Biozone in the peri-Gondwanan Europe: graptolite assemblages, its stratigraphical range and paleobiogeography. Bulletin of the Czech Geological Survey, 71: 171-8.

Štorch, P., 1998. Graptolites of the Pribylograptus leptotheca and Lituigraptus convolutus biozones of Tmaň (Silurian, Czech Republic). Journal of the Czech Geological Society, 43: 209-72.

Štorch, P., Fryda, J., 2012. The late Aeronian graptolite sedgwickii event, associated positive carbon isotope excursion and facies changes in the Prague synform (Barrandian area, Bohemia). Geological Magazine, 149: 1089-1106.

Štorch, P., Loydell, D.K., 1992. Graptolites of the Rastrites linnaei Group from the European Llandovery (Lower Silurian). Neues Jahrbuch für Geologie und Paläontologie, Abhandlungen, 184 63-86.

Štorch, P., Massa, D., 2006. Middle Llandovery (Aeronian) graptolites of the western Murzuq Basin and AI Qarqaf Arch region, south-west Libya. Palaeontology, 49: 83-112.

Sudbury, M., 1958. Triangulate monograptids from the Monograptus gregarius Zone (lower Llandovery) of the Rheidol Gorge (Cardiganshire). Philosophical Transactions of the Royal Society of London, B241: 485-555.

Toghill, P., 1968. The graptolite assemblages and zones of the Birkhill Shales (Lower Silurian) at Dobb's Linn. Palaeontology, 11: $654-658$

Torsvik, T., Cocks, L.R.M., 2013. New global palaeogeographical reconstructions for the Early Palaeozoic and their generation. Geological Society Memoirs, 38: 5-24.
Vaslet, D., Kellog, K.S., Berthiaux, A., Le Strat, P., Pierre-Louis, V., 1987. Explanatory notes to the geologic map of the Baq'a Quadrangle, Kingdom of Saudi Arabia. Geoscience Map GM-116C, scale 1:250,000, sheet 27F. Ministry of Petroleum and Mineral Resources, Deputy Ministry for Mineral Resources.

Vaslet, D., 1989. Late Ordovician glacial deposits in Saudi Arabia: a lithostratigraphic revision of the Early Palaeozoic succession. Deputy Ministry for Mineral Resources, Professional Papers, PP-3: 15-44.

Vaslet, D., Janjou, D., Robelin, C., Al-Muallem, M.S., Halawani, M.A., Brosse, J.-M., Breton, J.-P., Courbouleix, S., Roobol, M.J., Dagain, J., 1994. Geologic Map of the Tayma Quadrangle, sheet 27 C, Kingdom of Saudi Arabia. Saudi Arabian Deputy Ministry for Mineral Resources Geoscience Map GM-134, 1:250,000, with text, $51 \mathrm{pp}$.

Wender, L.E., Bryant, J.W., Dickens, M.F., Neville, A.S. Al-Moqbel, A.M., 1998. Paleozoic (Pre-Khuff) hydrocarbon geology of the Ghawar Area, Eastern Saudi Arabia. GeoArabia, 3: 273-302.

Williams, M., Zalasiewicz, J.A., Rushton, A.W.A., Loydell, D.K., Barnes, R.P., 2003. A new, stratigraphically significant Torquigraptus species (graptolite) from the Central Belt of the Southern Uplands Terrane, Scotland. Scottish Journal of Geology, 39: 17-28.

Zalasiewicz, J.A., 1990. Silurian graptolite biostratigraphy in the Welsh Basin. Journal of the Geological Society, 147: 619-22.

Zalasiewicz, J.A., 1996. Aeronian (Silurian: Landovery) graptolites from central Wales. Geologica et Palaeontologica, 30: 1-14

Zalasiewicz, J.A., Tunnicliff, S.P., 1994. Uppermost Ordovician to Lower Silurian graptolite biostratigraphy of the Wye Valley, Central Wales. Palaeontology, 37: 695-720.

Zalasiewicz, J.A., Williams, M., Miller, M.A., Page, A., Blackett, E., 2007. Llandovery graptolites from Saudi Arabia: first confirmed record of Telychian rocks from the Arabian peninsula. Geoarabia, 12: 15-36.

Zalasiewicz, J.A., Taylor, L., Rushton, A.W.A., Loydell, D.K., Rickards, R.B., Williams, M., 2009. Graptolites in British stratigraphy. Geological Magazine, 146: 785-850. 